\title{
Articles
}

\section{(Bis(imino)aryl)rhodium(III) Halide and Methyl Compounds}

\author{
Wilhelmus J . Hoogervorst, ${ }^{\dagger}$ Kees Goubitz, ${ }^{\dagger} \mathrm{J}$ an Fraanje, ${ }^{\dagger}$ Martin Lutz, ${ }^{\ddagger}$ \\ Anthony L. Spek, ${ }^{\ddagger}$ J an Meine Ernsting, ${ }^{\dagger}$ and Cornelis J . Elsevier*, ${ }^{\dagger}$ \\ Van 't Hoff I nstitute for Molecular Sciences, Universiteit van Amsterdam, Nieuwe Achtergracht \\ 166, NL-1018 WV Amsterdam, The Netherlands, and Bijvoet Center for Biomolecular \\ Research, Vakgroep Kristal- en Struktuurchemie, Utrecht University, Padualaan 8, \\ NL-3584 CH Utrecht, The Netherlands
}

Received May 27, 2004

The synthesis and X-ray crystal structure of a number of aryl-rhodium dihalide and arylrhodium methyl halide complexes $\left[\mathrm{RhX}_{2}(\mathrm{NCN})\right]$ and $\left[\mathrm{RhX}\left(\mathrm{CH}_{3}\right)(\mathrm{NCN})\right]$ with bis(imino)aryl type tridentate NCN ligands are reported. These are interesting examples of compounds on the reaction coordinate of $\mathrm{C}$-halogen, halogen-hal ogen, and $\mathrm{C}-\mathrm{C}$ bond-forming and bondbreaking reactions. Due to the strong $\mathrm{C}\left(\mathrm{sp}^{2}\right)-\mathrm{C}\left(\mathrm{sp}^{3}\right)$ bond, only very few transition-metal compounds having an aryl as well as a methyl group bonded to the same metal atom are known and, usually, reductive el imination occurs. It has been shown that the imine moieties of the isophthalaldimine ligand in the rhodium(III) dihalide compounds $\left[\operatorname{RhX}_{2}(\mathrm{NCN})\right]$ coordinate quite strongly, since the addition of an excess of pyridine or $\mathrm{PPh}_{3}$ resulted in their coordination to rhodium, not in substitution of the imine moieties. Transmetalation of the rhodium(III) isophthalaldimine dihalide compounds $\left[\mathrm{RhX}_{2}(\mathrm{NCN})\right]$ with $\mathrm{Me}_{2} \mathrm{Zn}$ provides novel rhodium(III) methyl halide isophthalaldimine compounds $\left[\mathrm{RhX}\left(\mathrm{CH}_{3}\right)(\mathrm{NCN})\right]$. These diorganorhodium compounds are stable and do not give rise to reductive $\mathrm{C}-\mathrm{C}$ coupling, which must be partially ascribed to the relatively high el ectron density on the rhodium(III) center, due to the strongly electron donating imine moieties.

\section{Introduction}

We recently have shown that diorganoplatinum isophthalaldimine compounds can be formed in a transmetalation reaction of a platinum isophthalaldimine halide and a transmetalating reagent (Chart $1 ; \mathbf{A}, R^{\prime}=$ $\left.\mathrm{C} \equiv \mathrm{CRSiMe}_{3}, \mathrm{CH}_{3}\right)^{1}{ }^{1,2}$ In this paper we describe organorhodium and diorganorhodium derivatives of the isophthalaldimine ligand. Diorganorhodium compounds are relevant to investigations of catalytic reactions and primary processes involving $\mathrm{C}-\mathrm{X}$ and $\mathrm{C}-\mathrm{C}$ bonds. ${ }^{3,4}$ Many examples of diorganorhodium compounds containing a variety of ligands have been published.5,6

The isophthalaldimine ligand is a covalently bound and meridional coordinating [D-C-D] type ligand (B;

\footnotetext{
* To whom correspondence should be addressed. E-mail: elsevier@ science.uva.nl.

† Universiteit van Amsterdam

₹ Utrecht University.

(1) Hoogervorst, W.J .; Koster, A. L.; Lutz, M.; Spek, A. L.; Elsevier, C. J. Organometallics 2004, 23, 1161-1164.

(2) Hoogervorst, W. J.; Elsevier, C. J .; Lutz, M.; Spek, A. L. Organometallics 2001, 20, 4437-4440.

(3) Rybtchinski, B.; Milstein, D. Angew. Chem., Int. Ed. 1999, 38, 870-883.

(4) Cornils, B., Herrmann, W. A., Eds. In Applied Homogeneous Catalysis with Organometallic Compounds: A Comprehensive Handbook in Three Volumes; Wiley-VCH: Weinheim, Germany, 2002.

(5) Hughes, R. P. In ComprehensiveOrganometallic Chemistry; Abel, E. W., Stone, F. G. A., Wilkinson, G., Eds.; Pergamon Press: Oxford, U.K., 1982; Vol. 5, p 277.
}

\section{Chart 1}
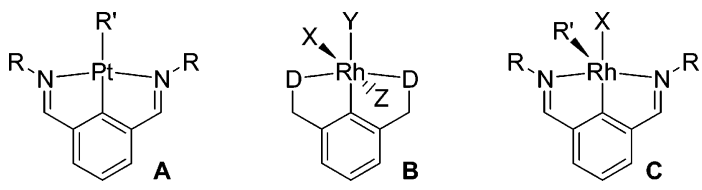

see Chart 1). Since the first publication concerning a [D-C-D] type ligand in 1976, in which Moulton and Shaw describe a [P-C-P] ligand having bis(tri-tertbutylphosphine) groups as donors, ${ }^{7}$ this area of organometallic chemistry has gained much interest. I nvestigations have focused on rhodium derivatives of phosphine [P-C-P] ligands, ${ }^{3,8-10}$ and also rhodium [N-C-N] compounds have been prepared where " $\mathrm{N}$ " denotes an amine, ${ }^{11-14}$ oxazoline, ${ }^{15,16}$ pyridine, ${ }^{17}$ or benzimidazole ${ }^{18}$ donor group.

(6) Sharp, P. R. In Comprehensive Organometallic Chemistry II: A Review of the Literature 1982-1994; Abel, E. W., Stone, F. G. A. Wilkinson, G., Eds.; Pergamon Press: Oxford, U.K., 1995; Vol. 8, p 115.

(7) Moulton, C. J .; Shaw, B. L. J . Chem. Soc., Dalton Trans. 1976, $1020-1024$.

(8) Kaska, W. C.; Nemeh, S.; Shirazi, A.; Potuznik, S. Organome tallics 1988, 7, 13-15.

(9) Nemeh, S.; J ensen, C.; Binamira-Soriaga, E.; Kaska, W. C. Organometallics 1983, 2, 1442-1447.

(10) Wang, K.; Goldman, M. E.; Emge, T. J .; Goldman, A. S. J . Organomet. Chem. 1996, 518, 55-68. 
However, rhodium compounds derived from isophthalaldimines are not known to date. In general, in an isophthalal dimine rhodium(III) compound (B; D = imine) three positions of the rhodium(III) coordination sphere can be occupied by the $\kappa^{3}-(\mathrm{N}-\mathrm{C}-\mathrm{N})$ coordinating isophthalaldimine ligand, and two additional positions can be occupied by anions. A sixth ligand may complete the coordination sphere.

Organorhodium [D-C-D] compounds, which are diorganorhodium compounds, have been prepared for [P-C-P] and [N-C-N] ligands. Oxidative addition of $\mathrm{CH}_{3} \mathrm{CH}_{2}$ l or $\mathrm{CF}_{3} \mathrm{CH}_{2}$ lo a [P-C-P]-Rh(I) compound resulted in the corresponding Rh(III) alkyl compounds. 19,20 Milstein et al. have investigated the activation of the $\left[\mathrm{P}\left(\mathrm{C}_{\text {aryl }}-\mathrm{C}_{\text {alkyl }}\right) \mathrm{P}\right]$ bond, which also leads to [P-C-P]rhodium al kyl compounds. ${ }^{19,21}$ Kaska and co-workers found that the (unintended) intramolecular $\mathrm{C}-\mathrm{H}$ activation of the tert-butylphosphine substituent of their [P-C-P] compound can lead to a diorganorhodium compound. ${ }^{9} \mathrm{~F}$ or the 2,6-bis((dimethylamino)methyl)phenyl [N-C-N] ligand, methyl and ethyl rhodium(III) derivatives have been described, ${ }^{12}$ which were prepared via transmetalation (with $\mathrm{AlMe}_{3}$ or $\mathrm{AlEt}_{3}$ ) or by oxidative addition (of Mel).

Suitable precursors for the synthesis of organorhodium(III) derivatives of the isophthalaldimine ligand would be rhodium(III) isophthal aldimine dihalide compounds. A transmetalation by, for example, dimethylzinc, similar to that published previously, ${ }^{1}$ might lead to diorganorhodium(III) compounds of type $\mathbf{C}$ (Chart 1). In the rhodium(III) isophthalaldimine organo compounds, the geometry of the rhodium is expected to be square pyramidal, analogous to the compounds described previously. ${ }^{12,21}$

\section{Results}

Synthesis of Rhodium(III) Isophthalaldimine Halide Compounds. (a) Ligand Synthesis. The isophthalaldimine ligands, i.e., 2-bromoisophthalaldimines (1) and 2-iodoisophthalal dimines (2), were prepared in a manner similar to the method described in our previous paper $^{2}$ (see Scheme 1 and Table 1 for yield and ligand definition).

2-I odoi sophthalal dehyde (6) is prepared in four steps from 2-bromoisophthalal dehyde (3) (see the Experimen-

(11) Hiraki, K.; Fuchita, Y.; Ohta, Y.; Tsutsumida, J .; Hardcastle, K. I. J . Chem. Soc., Dalton Trans. 1992, 833.

(12) van der Zeijden, A. A. H.; van Koten, G.; Ernsting, J. M.; Elsevier: C. J .; Krijnen, B.; Stam, C. H. J . Chem. Soc., Dalton Trans. 1989, 317-324.

(13) van der Zeijden, A. A. H.; van Koten, G.; Luijk, R.; Vrieze, K.; Slob, C.; Krabbendam, H.; Spek, A. L. Inorg. Chem. 1988, 27, 10141019.

(14) van der Zeijden, A. A. H.; van Koten, G.; Nordemann, R. A.; Kojic-Prodic, B.; Spek, A. L. Organometallics 1988, 7, 1957-1966.

(15) Motoyama, Y.; Kawakami, H.; Shimozono, K.; Aoki, K.; Nishiyama, H. Organometallics 2002, 21, 3408-3416.

(16) Gerisch, M.; Krumper, J . R.; Bergman, R. G.; Tilley, T. D. J . Am. Chem. Soc. 2001, 123, 5818-5819.

(17) Nonoyama, M. Polyhedron 1985, 4, 765-768.

(18) Gayathri, V.: Leelamani, E. G.; Gowda, N. M. N.; Reddy, G. K N. Polyhedron 1999, 18, 2351-2360.

(19) van der Boom, M. E.; Liou, S.-Y.; Ben-David, Y.; Gozin, M.; Milstein, D. J . Am. Chem. Soc. 1998, 120, 13415-13421.

(20) van der Boom, M. E.; Higgitt, C. L.; Milstein, D. Organometallics 1999, 18, 2413-2419.

(21) Rybtchinski, B.; Vigalok, A.; Ben-David, Y.; Milstein, D. J . Am. Chem. Soc. 1996, 118, 12406-12415.
Scheme 1. Synthesis of 2-Bromo- and 2-Iodoisophthalaldimines 1 and 2

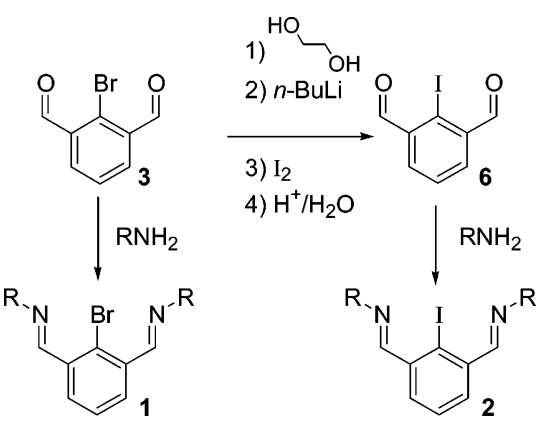

Table 1. Yields of 2-Bromo- and

2-lodoisophthalaldimines 1 and 2

\begin{tabular}{cccc}
\hline suffix & imine substituent & yield of $\mathbf{1}, \%$ & yield of $\mathbf{2 ,} \%$ \\
\hline $\mathbf{a}$ & methyl & 80 & \\
$\mathbf{b}$ & isopropyl & 95 & 86 \\
$\mathbf{c}$ & tert-butyl & 88 &
\end{tabular}

\section{Scheme 2. Oxidative Addition of 2-Halogenoisophthalaldimines to Rh(I) Chloride Precursors}
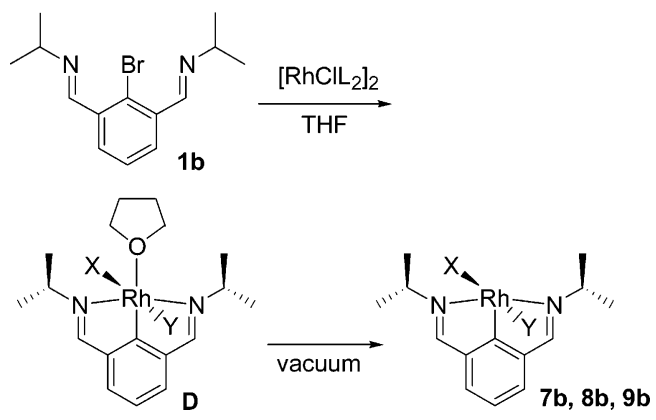

tal Section). The intermediate bromoacetal (4) and iodoacetal (5) are not depicted.

(b) Oxidative Addition of 2-Halogenoisophthalaldimines to $\mathbf{R h}(\mathbf{I})$ Chloride Precursors. Analogous to the synthesis of platinum(II) isophthalaldimine compounds, 1,2 the synthesis of the rhodium(III) isophthalaldimine compounds was attempted by oxidative addition of a 2-bromo- or 2-iodoisophthalaldimine to $\left[\mathrm{Rh}(\mathrm{coe}){ }_{2} \mathrm{Cl}\right]_{2}$ (coe $=$ cyclooctene) as the $\mathrm{Rh}(\mathrm{I})$ precursor. The oxidative addition reaction between $\mathbf{l b}(\mathrm{R}=$ isopropyl) and $\left[\mathrm{Rh}(\mathrm{coe}){ }_{2} \mathrm{Cl}\right]_{2}$ was performed at $60{ }^{\circ} \mathrm{C}$ (Scheme 2).

Analysis of the reaction mixture by means of ${ }^{1} \mathrm{H} N M R$ spectroscopy reveal ed the presence of three compounds in a 1:2:1 ratio due to the redistribution of the halides; these compounds were identified as $\mathbf{7 b}(X=Y=C l)$, 8b $(X=C l, Y=B r)$, and $9 b(X=Y=B r)$. The purification of the products from unreacted isophthalaldimine ligand and liberated cyclooctene was easily accomplished by washing with diethyl ether or pentane. The yield of the mixture consisting of $\mathbf{7 b}, \mathbf{8 b}$, and $\mathbf{9 b}$ was $91 \%$ in all.

In the ${ }^{1} \mathrm{H}$ NMR spectrum, the three compounds give distinct signals for the imine protons and showed a coordination-induced shift of $0.3-0.4 \mathrm{ppm}$, which points to their coordination, next to the appearance of a signal which was a doublet, due to the ${ }^{3} \mathrm{~J}\left({ }^{1} \mathrm{H},{ }^{103} \mathrm{Rh}\right)$ coupling constant of 3-4 Hz. These three compounds were all rhodium isophthalal dimine compounds. Evidence was obtained from a $2 \mathrm{D}{ }^{1} \mathrm{H},{ }^{103} \mathrm{Rh}$ NMR spectrum of the 
Scheme 3. Halide Metathesis in [RhXY(NCN)] Compounds $7 b-9 b$

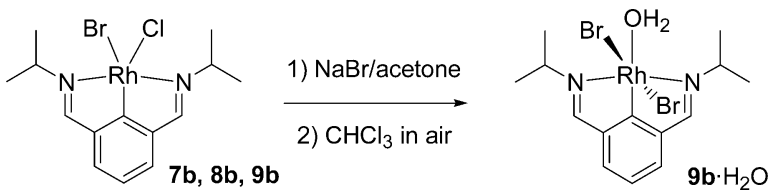

Scheme 4. Halide Metathesis in [RhXY(NCN)] Compounds 7c-9c

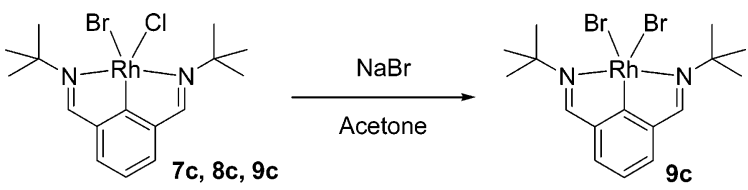

mixture of compounds, which unequivocally showed that each of the three resonances correlates with an individual ${ }^{103} \mathrm{Rh}$ resonance (vide infra).

Single crystals of a 1:2:1 mixture of $\mathbf{7 b}, \mathbf{8 b}$, and $\mathbf{9 b}$ could be obtained from a THF solution, and from an $X$-ray structure analysis it appears that the halide distribution is approximately $50 \%$ chloride vs $50 \%$ bromide and that a THF molecule coordinates to the rhodium atom. This THF molecule is absent when $\mathbf{7 b}$, $\mathbf{8 b}$, and $\mathbf{9 b}$ were isolated and dried in vacuo. This product mixture with a THF molecule coordinated to the rhodium atom is identified as compound $\mathbf{D}$ (see Scheme 2); its crystal structure will be decribed below. Compounds $\mathbf{7 b}$ and $\mathbf{9 b}$ have $\mathrm{C}_{2 v}$ symmetry, which is apparent from the isopropyl methyl signals in their ${ }^{1} \mathrm{H}$ and ${ }^{13} \mathrm{C}$ NMR spectra (in $\mathrm{CD}_{3} \mathrm{OD}$ ), while $8 \mathbf{b}$ has only $\mathrm{C}_{\mathrm{s}}$ symmetry. The exchange may occur either via dissociation and statistical reassociation of the halides or via intermolecular contacts via bridging halides. ${ }^{13}$

For $\mathbf{l a}(\mathrm{R}=$ methyl, $86 \%)$ and $\mathbf{l c}(\mathrm{R}=$ tert-butyl, $91 \%)$ an analogous reaction at $60^{\circ} \mathrm{C}$ resulted in the formation of rhodium(III) isophthalaldimine compounds, as a mixture of three compounds, similar to the case for the oxidative addition of $\mathbf{1 b}$.

By adding excess $\mathrm{NaBr}$ to the reaction product mixture of $\mathbf{7 b}-\mathbf{9 b}(\mathrm{R}=$ isopropyl, $\mathrm{X}, \mathrm{Y}=\mathrm{Cl}, \mathrm{Br}$ ) dissolved in acetone, the chlorideanions were exchanged for bromides and this mixture was converted into one well-defined rhodium(III) isophthalal dimine compound. From a recrystallization from $\mathrm{CHCl}_{3}$ in air, the pure rhodium(III) isophthalal dimine dibromide aqua complex $\left(\mathbf{9 b} \cdot \mathrm{H}_{2} \mathrm{O}\right)$ was obtained (see Scheme 3$)$. The water molecule originates from the air during the crystallization from $\mathrm{CHCl}_{3}$. The product $\mathbf{9 b} \cdot \mathrm{H}_{2} \mathrm{O}$ was obtained as crystals which were suitable for a single-crystal X-ray structure analysis (vide infra).

When the chlorides in $\mathbf{7 c}-\mathbf{9 c}(\mathrm{R}=$ tert-butyl, $\mathrm{X}, \mathrm{Y}=$ $\mathrm{Cl}, \mathrm{Br}$ ) were exchanged for bromides in an analogous double sequential exchange reaction (see Scheme 4), the rhodium(III) isophthalaldimine dibromide compound (9c) could be obtained in pure form. Compound $9 c$ was not a six-coordinated water complex but a five-coordinated rhodium compound, as was concluded from the elemental composition, which was much closer to the five-coordinated than the six-coordinated species (see Experimental Section).

Attempts to exchange the chlorides in $7 \mathbf{a}(\mathrm{R}=$ methyl) did not result in a pure dibromide compound; a small amount of chloride remained present after two sequen-
Table 2. ${ }^{103}$ h h NMR Spectroscopic Data, Measured in $\mathrm{CD}_{3} \mathrm{OD}$

\begin{tabular}{clllc}
\hline compd & \multicolumn{1}{c}{$\mathrm{R}$} & $\mathrm{X}$ & $\mathrm{Y}$ & $\delta\left({ }^{103} \mathrm{Rh}\right)$ \\
\hline $\mathbf{7 a}$ & methyl & $\mathrm{Cl}$ & $\mathrm{Cl}$ & 3888 \\
$\mathbf{8 a}$ & methyl & $\mathrm{Br}$ & $\mathrm{Cl}$ & 3733 \\
$\mathbf{9 a}$ & methyl & $\mathrm{Br}$ & $\mathrm{Br}$ & 3569 \\
$\mathbf{7 b}$ & isopropyl & $\mathrm{Cl}$ & $\mathrm{Cl}$ & 4185 \\
$\mathbf{8 b}$ & isopropyl & $\mathrm{Br}$ & $\mathrm{Cl}$ & 4027 \\
$\mathbf{9 b}$ & isopropyl & $\mathrm{Br}$ & $\mathrm{Br}$ & 3862 \\
$\mathbf{1 0 b}$ & isopropyl & $\mathrm{I}$ & $\mathrm{Cl}$ & 3674 \\
$\mathbf{1 1 b}$ & isopropyl & $\mathrm{I}$ & $\mathrm{I}$ & 3176 \\
$\mathbf{7 c}$ & tert-butyl & $\mathrm{Cl}$ & $\mathrm{Cl}$ & 4587 \\
$\mathbf{8 c}$ & tert-butyl & $\mathrm{Br}$ & $\mathrm{Cl}$ & 4374 \\
$\mathbf{9 c}$ & tert-butyl & $\mathrm{Br}$ & $\mathrm{Br}$ & 4107
\end{tabular}

tial exchange reactions with $\mathrm{NaBr}$. The reaction was hampered by the low solubility of compound 7a. Attempts to exchange the bromides in $\mathbf{7 b}(\mathrm{R}=$ isopropyl) to chlorides via an analogous reaction with $\mathrm{NaCl}$ in acetone were unsuccessful. Generally, substituting a halide for one with lower atomic number is unfavorable.22

Whereas the oxidative addition is successful for $\mathbf{l a}-\mathbf{c}$, it has previously been published that an analogous reaction of the 2-bromobis((dimethylamino)meth$\mathrm{yl}$ )phenyl ligand was unsuccessful. ${ }^{13}$ I n contrast, in that case the cycl ometalation of the parent ligand by $\mathrm{RhCl}_{3}$. $3 \mathrm{H}_{2} \mathrm{O}$ was successful and resulted in a rhodium bis((dimethylamino)methyl)phenyl dichloride aqua complex. ${ }^{13}$ However, we found that this route was unsuccessful for the parent di-N-isopropylisophthalaldimine ligand.

(i) Oxidative Addition of 2-lodoisophthalaldimines to a $\mathbf{R h}$ (I) Precursor. Analogous to the oxidative addition reaction in the $\mathrm{C}-\mathrm{Br}$ bond of the 2-bromoisophthalal dimine ligands (Scheme 2), an oxidative addition of a C $-I$ bond of the 2-iodoisophthalaldimine $\mathbf{2 b}$ to a $\mathrm{Rh}^{\prime} \mathrm{Cl}$ precursor $\left(\left[\mathrm{Rh}(\mathrm{Coe})_{2} \mathrm{Cl}\right]_{2}\right.$ ) was performed. The composition of the product mixture was similar to that for the 2-bromoisophthalaldimine ligands. Three different isophthalaldimine rhodium(III) compounds (7b, 10b, and $\mathbf{1 1 b}$ ) were also formed in a 1:2:1 ratio in this case. When $\left[R h \text { (ethene) }{ }_{2} \mathrm{Cl}\right]_{2}$ was used as precusor instead of $\left[\mathrm{Rh}(\mathrm{coe})_{2} \mathrm{Cl}\right]_{2}$, the same ratios were obtained.

When the isophthalal dimine Rh(III) bromide/chloride product mixture $\mathbf{7 b}-\mathbf{9 b}(\mathrm{R}=$ isopropyl) was subjected to a halide exchange reaction with sodium iodide in acetone, analogous to Scheme 4, the five-coordinate $\mathrm{Rh}(\mathrm{III})$ isophthalal di mine diiodide compound (11b) was obtained pure.

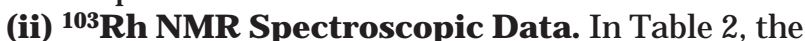
${ }^{103} \mathrm{Rh}$ NMR data of the prepared compounds have been assigned. This assignment is based on comparison of product mixtures $\mathbf{7 b}-\mathbf{9 b}$ and $\mathbf{7 b}, \mathbf{1 0 b}, \mathbf{1 1} \mathbf{b}$ and on the pure compounds formed in halide exchange reactions. The different halide surroundings of the rhodium in compounds 7-11 are reflected in their ${ }^{103} \mathrm{Rh}$ chemical shifts and are in accordance with a previously found trend. ${ }^{23}$

(iii) X-ray Crystal Structure Determinations of D and $\mathbf{9 b} \cdot \mathbf{H}_{2} \mathrm{O}$. The structures of $\mathbf{D}$ and $\mathbf{9 b} \cdot \mathrm{H}_{2} \mathrm{O}$ are presented in Figures 1 and 2, respectively; selected bond lengths and angles are presented in Table 3. The crystal structure of $\mathbf{9 b} \cdot \mathrm{H}_{2} \mathrm{O}$ has space group $\mathrm{C} 2 / \mathrm{c}$ and a 2 -fold

(22) J ude, H.; Krause Bauer, J . A.; Connick, W. B. Inorg. Chem. 2002, 41, 2275-2281. 66. 


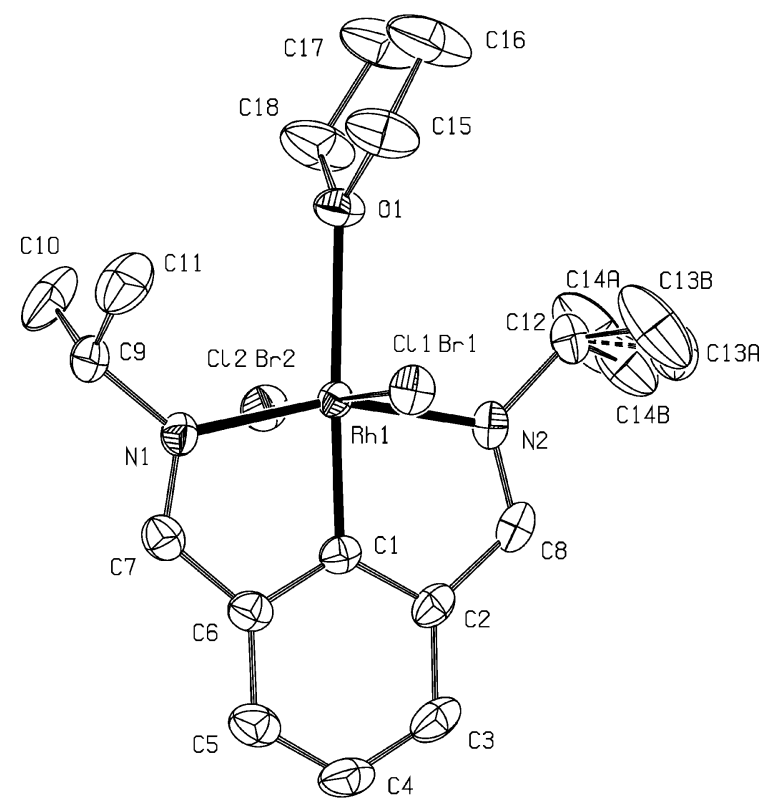

Figure 1. Displacement ellipsoid pl ot of compound $\mathbf{D}$ with ellipsoids drawn at the $50 \%$ probability level. The cocrystallized molecules of THF and the hydrogen atoms are omitted for clarity.

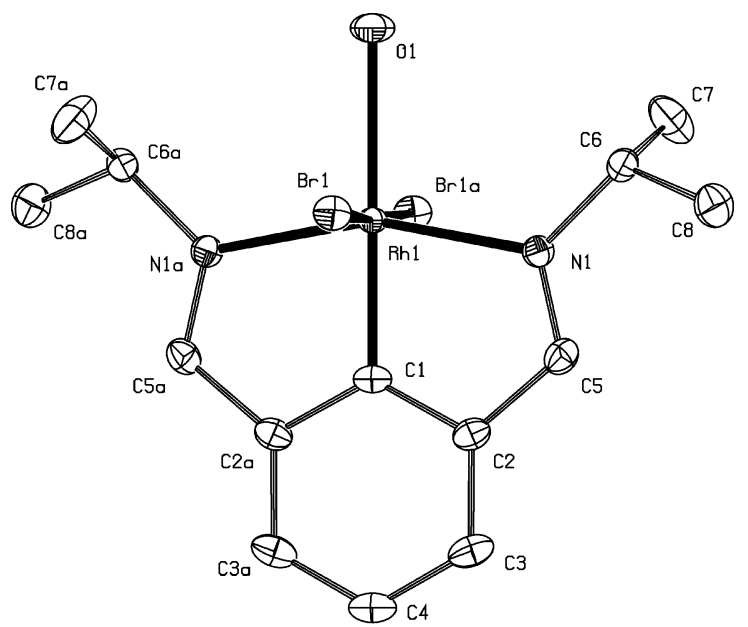

Figure 2. Displacement ellipsoid plot of $\mathbf{9 b} \cdot \mathrm{H}_{2} \mathrm{O}$ with ellipsoids drawn at the $50 \%$ probability level. The hydrogen atoms are omitted for clarity.

symmetry axis through $\mathrm{O}(1), \mathrm{Rh}(1), \mathrm{C}(1)$, and $\mathrm{C}(4)$; consequently, both sides of the molecule (in Figure 2, the left- and right-hand sides) have the same bond lengths and angles. In the crystal structures of both $\mathbf{D}$ and $\mathbf{9 b} \cdot \mathrm{H}_{2} \mathrm{O}$, the $\mathrm{Rh}$ has a distorted-octahedral surrounding with an oxygen atom of a THF molecule or a water molecule occupying the sixth position, respectively. The distortion is merely caused by the $\mathrm{N}-\mathrm{Rh}-\mathrm{N}$ angle of $159.64(9)^{\circ}$ for $\mathbf{D}$ and $159.36(8)^{\circ}$ for $\mathbf{9 b} \cdot \mathrm{H}_{2} \mathrm{O}$, respectively, which deviate severely from $180^{\circ}$. This small angle is caused by geometric constraints of the isophthalaldimine ligand (adjacent five and six-membered rings), and this angle is slightly larger than the $\mathrm{N}-\mathrm{M}-\mathrm{N}$ angles found in the square planar $\mathrm{Pt}(\mathrm{II})$ complexes $\left(157.21(9)-157.63(8)^{\circ}\right)$ described in our previous papers. ${ }^{1,2}$ The other bond lengths and angles in D and $\mathbf{9 b} \cdot \mathrm{H}_{2} \mathrm{O}$ do not deviate significantly from those of the comparable Pt(II) complexes.
Table 3. Selected Bond Lengths $(\AA)$ and Angles (deg) for $D$ and $9 b \cdot \mathrm{H}_{2} \mathrm{O}$

\begin{tabular}{llll}
\hline \multicolumn{3}{c}{$\mathrm{D}^{\mathrm{a}}$} & \multicolumn{2}{c}{$\mathbf{9 b} \cdot \mathrm{H}_{2} \mathrm{O}^{\mathrm{b}}$} \\
\hline $\mathrm{Rh}(1)-\mathrm{Cl}(1) / \mathrm{Br}(1)$ & $2.4332(4)$ & $\mathrm{Rh}(1)-\mathrm{Br}(1)$ & $2.4716(2)$ \\
$\mathrm{Rh}(1)-\mathrm{Cl}(2) / \mathrm{Br}(2)$ & $2.4185(4)$ & & \\
$\mathrm{Rh}(1)-\mathrm{N}(1)$ & $2.100(2)$ & $\mathrm{Rh}(1)-\mathrm{N}(1)$ & $2.0792(15)$ \\
$\mathrm{Rh}(1)-\mathrm{N}(2)$ & $2.058(2)$ & & \\
$\mathrm{Rh}(1)-\mathrm{O}(1)$ & $2.3579(19)$ & $\mathrm{Rh}(1)-\mathrm{O}(1)$ & $2.306(2)$ \\
$\mathrm{Rh}(1)-\mathrm{C}(1)$ & $1.898(2)$ & $\mathrm{Rh}(1)-\mathrm{C}(1)$ & $1.904(2)$ \\
$\mathrm{N}(1)-\mathrm{C}(7)$ & $1.293(3)$ & $\mathrm{N}(1)-\mathrm{C}(5)$ & $1.295(2)$ \\
$\mathrm{N}(2)-\mathrm{C}(8)$ & $1.291(4)$ & & \\
$\mathrm{O}(1)-\mathrm{C}(18)$ & $1.432(4)$ & $\mathrm{n} . \mathrm{a}$. & \\
$\mathrm{O}(1)-\mathrm{C}(15)$ & $1.440(4)$ & & \\
$\mathrm{N}(1)-\mathrm{Rh}(1)-\mathrm{N}(2)$ & $159.64(9)$ & $\mathrm{N}(1)-\mathrm{Rh}(1)-\mathrm{N}(1) \mathrm{a}$ & $159.36(8)$ \\
$\mathrm{N}(1)-\mathrm{Rh}(1)-\mathrm{C}(1)$ & $79.55(10)$ & $\mathrm{N}(1)-\mathrm{Rh}(1)-\mathrm{C}(1)$ & $79.68(4)$ \\
$\mathrm{N}(2)-\mathrm{Rh}(1)-\mathrm{C}(1)$ & $80.09(10)$ & & \\
$\mathrm{O}(1)-\mathrm{Rh}(1)-\mathrm{N}(2)$ & $96.18(8)$ & $\mathrm{O}(1)-\mathrm{Rh}(1)-\mathrm{N}(1)$ & $100.32(4)$ \\
$\mathrm{O}(1)-\mathrm{Rh}(1)-\mathrm{N}(1)$ & $104.18(8)$ & & \\
$\mathrm{Cl}(1) / \mathrm{Br}(1)-\mathrm{Rh}(1)-$ & $91.23(6)$ & $\mathrm{Br}(1)-\mathrm{Rh}(1)-\mathrm{N}(1)$ & $86.85(4)$ \\
$\mathrm{N}(1)$ & & \\
$\mathrm{Cl}(1) / \mathrm{Br}(1)-\mathrm{Rh}(1)-$ & $88.70(6)$ & & \\
$\mathrm{N}(2)$ & & & \\
$\mathrm{Cl}(1) / \mathrm{Br}(1)-\mathrm{Rh}(1)-$ & $178.196(16)$ & $\mathrm{Br}(1)-\mathrm{Rh}(1)-\mathrm{Br}(1) \mathrm{a}$ & $175.941(11)$ \\
$\mathrm{Cl}(2) / \mathrm{Br}(2)$ & & & \\
$\mathrm{Cl}(1) / \mathrm{Br}(1)-\mathrm{Rh}(1)-$ & $90.72(7)$ & $\mathrm{Br}(1)-\mathrm{Rh}(1)-\mathrm{C}(1)$ & $92.030(5)$ \\
$\mathrm{C}(1)$ & & & \\
$\mathrm{O}(1)-\mathrm{Rh}(1)-\mathrm{C}(1)$ & $176.13(9)$ & $\mathrm{O}(1)-\mathrm{Rh}(1)-\mathrm{C}(1)$ & 180 \\
$\mathrm{Rh}(1)-\mathrm{O}(1)-\mathrm{C}(15)$ & $126.41(19)$ & $\mathrm{n} . \mathrm{a}$. & $\mathrm{n} . \mathrm{n}$. \\
$\mathrm{Rh}(1)-\mathrm{O}(1)-\mathrm{C}(18)$ & $125.42(19)$ & & \\
$\mathrm{C}(15)-\mathrm{O}(1)-\mathrm{C}(18)$ & $107.3(2)$ & $\mathrm{n} \cdot \mathrm{a}$. &
\end{tabular}

a The halogen positions are occupied by a mixture of $\mathrm{Br}$ and $\mathrm{Cl} .{ }^{b}$ Symmetry operation: (a) $1-x, y, 0.5-z$.

The structures of $\mathbf{D}$ and $\mathbf{9 b} \cdot \mathrm{H}_{2} \mathrm{O}$ are also comparable to a variety of structures of rhodium(III) dihalide compounds of the bis(oxazolinyl)phenyl ligand. ${ }^{24-26 ~ I n ~}$ these structures the $\mathrm{N}-\mathrm{Rh}-\mathrm{N}$ angles vary from 155.9 to $161.0^{\circ}$, the $\mathrm{N}-\mathrm{Rh}$ bond lengths vary from 2.04 to 2.12 $\AA$, and the $\mathrm{C}-\mathrm{Rh}$ bond lengths vary from 1.89 to 1.97 $\AA$. The values obtained for $\mathbf{D}$ and $\mathbf{9} \mathbf{b} \cdot \mathrm{H}_{2} \mathrm{O}$ are within these ranges. In comparison to a trans rhodium dichloride aqua complex of the bis((dimethylamino)methyl)phenyl ligand $\left(163.1(1)^{\circ}\right), 13$ the $\mathrm{N}-\mathrm{Rh}-\mathrm{N}$ angle is smaller in $\mathbf{D}\left(159.64(9)^{\circ}\right)$ and $\mathbf{9 b} \cdot \mathrm{H}_{2} \mathrm{O}\left(159.36(8)^{\circ}\right)$. This is due to the strain caused by the five and sixmembered adjacent rings. The $\mathrm{Rh}-\mathrm{N}$ bond lengths are much shorter in D and $\mathbf{9 b} \cdot \mathrm{H}_{2} \mathrm{O}: 2.058(2)-2.100(2) \AA$ compared to the values published previously of $2.152(3)-2.160(3) \AA .{ }^{13}$ In the structure of $\mathbf{D}$, the $\mathrm{Rh}(1)$, $\mathrm{C}(1), \mathrm{N}(1), \mathrm{N}(2)$, and $\mathrm{O}(1)$ atoms form a perfect plane; the sum of cis angles around the $\mathrm{Rh}(1)$ amounts to $360.0^{\circ}$. In $\mathbf{9 b} \cdot \mathrm{H}_{2} \mathrm{O}$ this plane is virtually flat, as a consequence of the 2 -fold symmetry.

In the structure of $\mathbf{D}$, the halides $\mathrm{Cl}(1) / \mathrm{Br}(1)$ and $\mathrm{Cl}(2) / \mathrm{Br}(2)$ are in substitutional disorder. The five- and six-membered rings of the isophthal al dimine-rhodium plane are each almost planar. For the Rh(1), N(1), C(1), $C(6), C(7)$ plane, the largest deviation is $0.007(2) \AA$, for the $\mathrm{Rh}(1), \mathrm{N}(2), \mathrm{C}(1), \mathrm{C}(2), \mathrm{C}(8)$ plane this deviation is $0.021(2) \AA$, and or the aryl ring the largest deviation is $0.010(2) \AA$. These three planes are almost coplanar: the angle between the first and the second is $1.41(11)^{\circ}$, that between the first and the third is $2.85(12)^{\circ}$, and that between the second and the third is $1.98(12)^{\circ}$. In the coordinating THF molecule in $\mathbf{D}$, the coordinating

(24) Motoyama, Y.; Okano, M.; Narusawa, H.; Makihara, N.; Aoki, K.: Nishiyama, H. Organometallics 2001, 20, 1580-1591.

(25) Motoyama, Y.; Shimozono, K.; Aoki, K.; Nishiyama, H. Organometallics 2002, 21, 1684-1696.

(26) Motoyama, Y.; Makihara, N.; Mikami, Y.; Aoki, K.; Nishiyama, H. Chem. Lett. 1997, 951-952. 

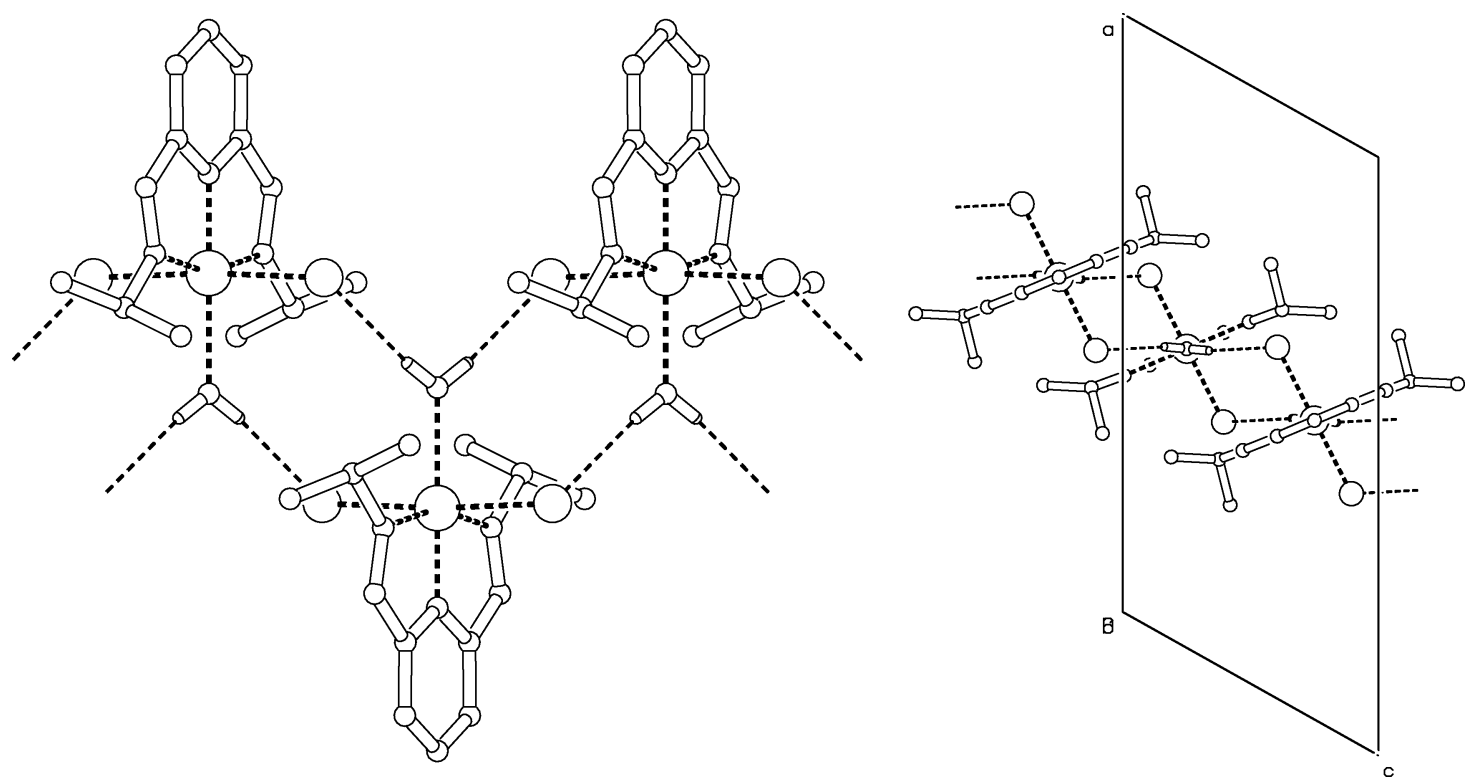

Figure 3. Different views of the hydrogen bonds in the crystal structure of $\mathbf{9 b}$. On the right-hand side, the view is on the ac plane across the $b$ axis. Hydrogen bonds are indicated with dashed lines.

oxygen atom is virtually coplanar with its surrounding atoms (Rh(1), $\mathrm{C}(15)$, and $\mathrm{C}(18)$ ); the sum of cis angles around $\mathrm{O}(1)$ is $359.11^{\circ}$. This coplanarity and the puckering of the THF ring results in a tilted coordination of the THF molecule. The angle of the least-squares plane of the THF molecule and the Rh-O bond is $24.0(2)^{\circ}$. In the molecular structure of $\mathbf{D}$, there is a small difference in Rh-N lengths; however, this can originate from the tilted coordination of the THF. At the moment of writing nine examples are known of end-on coordination of THF to rhodium(III $)^{27-34}$ and one example of coordination to rhodium(I). ${ }^{35}$ In comparison to these structures, the angles of the coordinated THF molecule in $\mathbf{D}$ have normal values. In the crystal of $\mathbf{D}$, for each molecule of D there are 1.5 molecules of THF cocrystallized, and in the unit cell, there are four molecules of $\mathbf{D}$ and six molecules of THF, two of which are disordered.

In the structure of $\mathbf{9} \mathbf{b} \cdot \mathrm{H}_{2} \mathrm{O}$, the five- and sixmembered rings in the isophthalaldimine-rhodium plane also are each almost planar. For the $\mathrm{Rh}(1), \mathrm{N}(1)$, $\mathrm{C}(1), \mathrm{C}(2), \mathrm{C}(5)$ plane, and for the $\mathrm{Rh}(1), \mathrm{N}(1) \mathrm{a}, \mathrm{C}(1)$, $\mathrm{C}(2) \mathrm{a}, \mathrm{C}(5) \mathrm{a}$ plane, the largest deviation is $0.013(3) \AA$; for the aryl ring, the largest deviation is $0.007(2) \AA$. These three planes are almost coplanar; the angle between the first and the second is $0.13(8)^{\circ}$, and those between the first and the third and between the second and the third are both $0.33(9)^{\circ}$. In the structure of $\mathbf{9 b} \cdot \mathrm{H}_{2} \mathrm{O}$, the water molecule forms hydrogen bonds with

(27) Agaskar, P. A.; Cotton, F. A.; Falvello, L. R.; Han, S. J . Am. Chem. Soc. 1986, 108, 1214.

(28) Bonar-Law, R. P.; Bickley, J . F.; Femoni, C.; Steiner, A. Dalton 2000, 4244 .

(29) Cotton, F. A.; Han, S.; Wang, W. Inorg. Chem. 1984, 23, 4762.

(30) Cotton, F. A.; Kim, Y. Eur. J . Solid State Inorg. Chem. 1994, 31,525 .

(31) Cotton, F. A.; Dikarev, E. V.; Stiriba, S.-E. Inorg. Chem. 1999, 38, 4877.

(32) Cotton, F. A.; Dikarev, E. V.; Petrukhina, M. A. Dalton 2000 4241.

(33) Crawford, C. A.; Matonic, J . H.; Streib, W. E.; Huffman, J . C.; Dunbar, K. R.; Christou, G. Inorg. Chem. 1993, 32, 3125.

(34) Pelagatti, P.; Bacchi, A.; Bobbio, C.; Carcelli, M.; Costa, M.; Pelizzi, C.; Vivorio, C. Organometallics 2000, 19, 5440.

(35) Weller, A. S.; Mahon, M. F.; Steed, J . W. J . Organomet. Chem. 2000, 614, 113
Table 4. Selected Hydrogen Bond Distances and Angles in 9b

\begin{tabular}{ccccc}
\hline \multicolumn{4}{c}{ hydrogen bonds } \\
$\mathrm{D}-\mathrm{H} \cdots \mathrm{A}$ & $\mathrm{D} \cdots \mathrm{A}, \AA$ & $\mathrm{D}-\mathrm{H}, \AA$ & $\mathrm{H} \cdots \mathrm{A}, \AA$ & $\begin{array}{c}\mathrm{D}-\mathrm{H} \cdots A \\
\mathrm{deg}\end{array}$ \\
\hline $\mathrm{O}(1)-\mathrm{H}(10) \cdots \mathrm{Br}(1)$ & $3.4462(12)$ & $0.81(2)$ & $2.64(2)$ & $173(3)$
\end{tabular}

Scheme 5. Addition of Pyridine-d $d_{5}$ to $9 b$

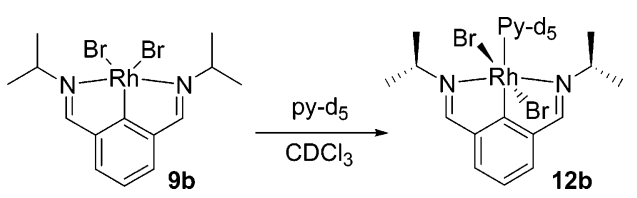

bromide atoms of two adjacent molecules in the crystal; this is depicted in Figure 3. The hydrogen bond lengths and angles are given in Table 4 . In this way infinite zigzag chains are formed in the direction of the $c$ axis. The hydrogen bonds in $\mathbf{9 b}$ are identical with hydrogen bonds between $\mathrm{O}-\mathrm{H}$ and $\mathrm{Cl}$ moieties in a trans-[bis((dimethylamino)methyl)phenyl ] $\mathrm{RhCl}_{2}\left(\mathrm{H}_{2} \mathrm{O}\right)$ compound published previously. ${ }^{13}$

Reaction of Rhodium(III) Isophthalaldimine Compounds with Additional Ligands. In most of the rhodium(III) isophthalaldimine dihalide compounds described so far, the rhodium center is five-coordinated. The available position in these rhodium compounds can be occupied by a THF or a water molecule, as was seen in the crystal structures of $\mathbf{D}$ and $\mathbf{9 b} \cdot \mathrm{H}_{2} \mathrm{O}$, respectively. When pyridine was added to the rhodium(III) isophthalaldimine dihalide compounds, immediately the pyridine adducts were formed. This was accomplished in an NMR tube, and the pyridine or pyridine- $\mathrm{d}_{5}$ complexes formed were identified by means of ${ }^{1} \mathrm{H}$ and ${ }^{103}$ Rh NMR spectroscopy. The reaction of the five-coordinate $\mathbf{9 b}$ and pyridine is depicted in Scheme 5. From the observed equivalence of the methyl group of the isopropyl groups in the ${ }^{1} \mathrm{H}$ NMR spectrum it was derived that the pyridine or pyridine- $\mathrm{d}_{5}$ occupies the position trans to the ipso aryl carbon, similar to the THF molecule and water molecules in $\mathbf{D}$ and $\mathbf{9 b} \cdot \mathrm{H}_{2} \mathrm{O}$, respectively.

When compound $\mathbf{9 b}$ was reacted with triphenylphos- 
Scheme 6. Addition of $\mathrm{PPh}_{3}$ to $9 \mathrm{~b}$

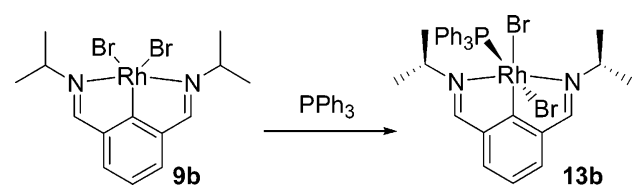

phine, the phosphine complex $\mathbf{1 3 b}$ was obtained. The complex geometry could be derived from the ${ }^{1} \mathrm{H}$ and ${ }^{13} \mathrm{C}$ NMR spectra. In contrast to $\mathbf{9 b} \cdot \mathrm{H}_{2} \mathrm{O}$ and the pyridine complex described above, in which the isopropyl methyl groups are equivalent due to the apical coordination of both bromides, in the $\mathrm{PPh}_{3}$ complex, they are not. From this inequivalence it was derived that the triphenylphosphine is coordinating apically and that one bromide has moved to an equatorial position (see Scheme 6). This configuration apparently is thermodynamically more stable than an equatorial coordination of the $\mathrm{PPh}_{3}$, caused by steric reasons and the strong mutual trans influence of both the aryl ring and the phosphine molecule.

In the ${ }^{13} \mathrm{C}$ NMR spectrum of $\mathbf{1 3 b}$, the ipso $\mathrm{Rh}-\mathrm{C}$ carbon was not observed; probably this rhodium-coupled signal was of very low intensity, due to the additional 2) $\left({ }^{31} \mathrm{P},{ }^{13} \mathrm{C}\right)$ coupling. Unfortunately, for this compound no correct elemental analysis could be obtained, due to the cocrystallization of various amounts of solvent. F or this compound its structure was unambiguously proven by an X-ray crystal structure analysis. In the crystal there are two independent complex molecules present, which differ significantly in their conformations. The two conformations of the $\mathrm{PPh}_{3}$ complex $\mathbf{1 3 \mathbf { b }}$ are depicted in Figure 4, and selected bond lengths and angles are presented in Table 5.

F or both conformations, the bond lengths and angles have normal values; they are also similar to those of $\mathbf{D}$ and $\mathbf{9 b} \cdot \mathrm{H}_{2} \mathrm{O}$, except for the $\mathrm{C}-\mathrm{Rh}$ bonds, which are longer. As a consequence, the $\mathrm{N}-\mathrm{Rh}-\mathrm{N}$ distances and angles are smaller in 13b (1.923(2), 1920(2) $\AA$ and $\left.157.23(7), 158.37(8)^{\circ}\right)$ than in D $\left(1.898(2) \AA, 159.64(9)^{\circ}\right)$ and $\mathbf{9 b} \cdot \mathrm{H}_{2} \mathrm{O}\left(1.904(2) \AA, 159.36(8)^{\circ}\right)$. As in the structures of $\mathbf{D}$ and $\mathbf{9 b} \cdot \mathrm{H}_{2} \mathrm{O}$, in $\mathbf{1 3} \mathbf{b}$ the five and six-membered rings in the isophthalaldimine-rhodium plane are almost planar and coplanar. The $\operatorname{Rh}(\mathrm{n})-\operatorname{Br}(\mathrm{In})$ bond lengths are much longer (2.6545(3) and 2.6450(3) $\AA$ ) than the $\operatorname{Rh}(\mathrm{n})-\operatorname{Br}(2 \mathrm{n})$ bond lengths (2.5311(3) and $2.5260(3) \AA$ ), which is in agreement with the strong trans influence of the carbon ligand, compared to the phosphine ligand.

(a) $\boldsymbol{\pi}-\boldsymbol{\pi}$ Interaction. When the molecules of 13b are viewed down the $P(n)-\operatorname{Rh}(n)-\operatorname{Br}(2 n)$ axis (Figure 4), it can clearly be seen that in residue 2 there is a superposition of two phenyl rings (one of the isophthalaldimine ligand and the other of the $\mathrm{PPh}_{3}$ ligand) which exhibit some $\pi$ stacking. The distance between the ring centroids is $3.4860(17) \AA$, and the angle between the rings is $18.92(15)^{\circ}$, while in residue 1 , these values are 3.8926(15) $\AA$ and $23.62(15)^{\circ}$. This $\pi-\pi$ interaction in residue 2 results in a tilting of the triphenylphosphine ligand toward the aryl ring of the isophthalaldimine ligand. For residue 1 , having no or little $\pi$ interaction, the $\mathrm{Rh}(1)-\mathrm{P}(1)-\mathrm{C}(151)$ angle $(\alpha$; see Figure 4) is $113.36(8)^{\circ}$, whereas for residue 2 the $R h(2)-P(2)-C(152)(\alpha)$ angle is $109.61(9)^{\circ}$. The $\mathrm{Rh}(\mathrm{n})-\mathrm{P}(\mathrm{n})-\mathrm{C}(15 \mathrm{n})$ angle shows an opposite, but much
Scheme 7. Transmetalation of $7 b-9 b$ with $\mathrm{Me}_{2} \mathrm{Zn}$

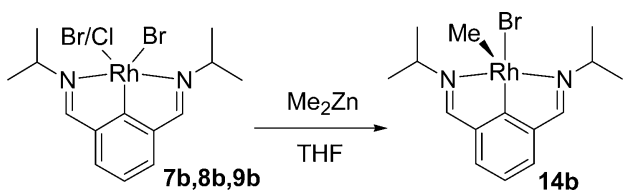

smaller, change. This angle is $90.48(6)^{\circ}$ for residue 1 and $92.11(7)^{\circ}$ for residue 2 .

Another indication for the alignment of the aryl ring of the isophthalaldimine ligand and the nearby phenyl ring of the triphenylphosphine ligand is the torsion angle between the $\mathrm{Rh}(\mathrm{n})-\mathrm{C}(1 \mathrm{n})$ and the $\mathrm{P}(\mathrm{n})-\mathrm{C}(15 \mathrm{n})$ bond. F or residue 1 the $\mathrm{Rh}(1)-\mathrm{C}(11)-\mathrm{P}(1)-\mathrm{C}(151)$ angle is $-26.98(14)^{\circ}$; for residue 2 , in which the $\pi-\pi$ interaction causes a better alignment, the Rh(2)-C(12)$\mathrm{P}(2)-\mathrm{C}(152)$ angle is $-5.77(17)^{\circ}$.

It can also be seen in Figure 4 that in residue 2 $\mathrm{Br}(12)$ is bending away from the phosphine ligand; in this residue, the $\mathrm{Br}(12)-\mathrm{Rh}(2)-\mathrm{C}(12)$ angle is $170.53(7)^{\circ}$, while in the other residue this angle is closer to linear, $176.28(7)^{\circ}$. This deviation is probably caused by steric hindrance between this bromide and the $\mathrm{C}(262)-\mathrm{H}(262)$ and $\mathrm{C}(282)-\mathrm{H}(282)$ bonds. The $\mathrm{Br}-\mathrm{H}$ distances are 2.6699 and $2.7421 \AA$, respectively.

Synthesis of Rhodium(III) Isophthalaldimine Methyl Halide Compounds. When the rhodium(III) isophthalaldimine dihalide compounds were subjected to a transmetalation with dimethylzinc at room temperature, rhodium(III) isophthal aldimine methyl halide compounds were formed (Scheme 7). When the rhodium(III) isophthalal dimine dibromide aqua complex $\mathbf{9 b} \cdot \mathrm{H}_{2} \mathrm{O}$ ( $R=$ isopropyl) was used, compound $\mathbf{1 4 b}$ was obtained. It is noteworthy that when the rhodium(I II) isophthalaldimine bromide/chloride mixture $\mathbf{7 b} \mathbf{- 9 b}$ was applied in a similar transmetalation, $\mathbf{1 4 b}$ was the only compound obtained, as inferred from ${ }^{1} \mathrm{H}$ and ${ }^{103} \mathrm{Rh}$ NMR spectroscopic analysis, albeit in lower yield.

In the ${ }^{1} \mathrm{H}$ NMR spectrum of $\mathbf{1 4 b}$, the diastereotopic isopropyl methyl groups show two doublets. At $296 \mathrm{~K}$ $\left(\mathrm{CDCl}_{3}, 500 \mathrm{MHz}\right)$, the $\mathrm{CH}_{3} \mathrm{CHCH}_{3}$ and the $\mathrm{Rh}-\mathrm{CH}_{3}$ protons give broad signals, which are sharp at $313 \mathrm{~K}$; for the latter signal, the ${ }^{3} \mathrm{~J}\left({ }^{1} \mathrm{H},{ }^{103} \mathrm{Rh}\right)$ coupling was $2 \mathrm{~Hz}$. Also in the ${ }^{13} \mathrm{C}$ NMR spectrum at $298 \mathrm{~K}$ many broad signals were observed. At $313 \mathrm{~K}$ all the signals could be assigned; the $\mathrm{Rh}-\mathrm{C}_{\mathrm{ipso}}$ signal was observed at 200.0 ppm with a ${ }^{1} \mathrm{~J}\left({ }^{13} \mathrm{C},{ }^{103} \mathrm{Rh}\right)$ value of $31 \mathrm{~Hz}$, and the $\mathrm{Rh}-\mathrm{CH}_{3}$ signal was observed at $1.2 \mathrm{ppm}$ with a ${ }^{1} \mathrm{f}\left({ }^{13} \mathrm{C},{ }^{103} \mathrm{Rh}\right)$ value of $28 \mathrm{~Hz}$. For the $\mathrm{C}=\mathrm{N}$ carbon no 2) $\left({ }^{13} \mathrm{C},{ }^{103} \mathrm{Rh}\right)$ coupling could be determined. At $313 \mathrm{~K}$ the indicated carbons of the $\mathrm{CH}_{3} \mathrm{CHCH}_{3}$ groups gave broadened signals, reflecting the asymmetry of the isopropyl group. The broadening of these signals is probably due to hindered rotation of the isopropyl groups.

When the rhodium(III) isophthalaldimine iodide/ chloride mixture $\mathbf{7 b}, \mathbf{1 0 b}$, and $\mathbf{1 1 b}(\mathrm{R}=$ isopropyl) was treated with dimethylzinc in a similar reaction, the rhodium(III ) isophthalal dimine methyl iodide compound 15b was obtained. However, as inferred from ${ }^{1} \mathrm{H}$ and ${ }^{103}$ Rh NMR spectroscopic analysis, a small amount of starting material was present, which was identified as the rhodium(III) isophthalaldimine di iodide compound 11b, which apparently is quite unreactive toward di- 


\section{Residue 1}
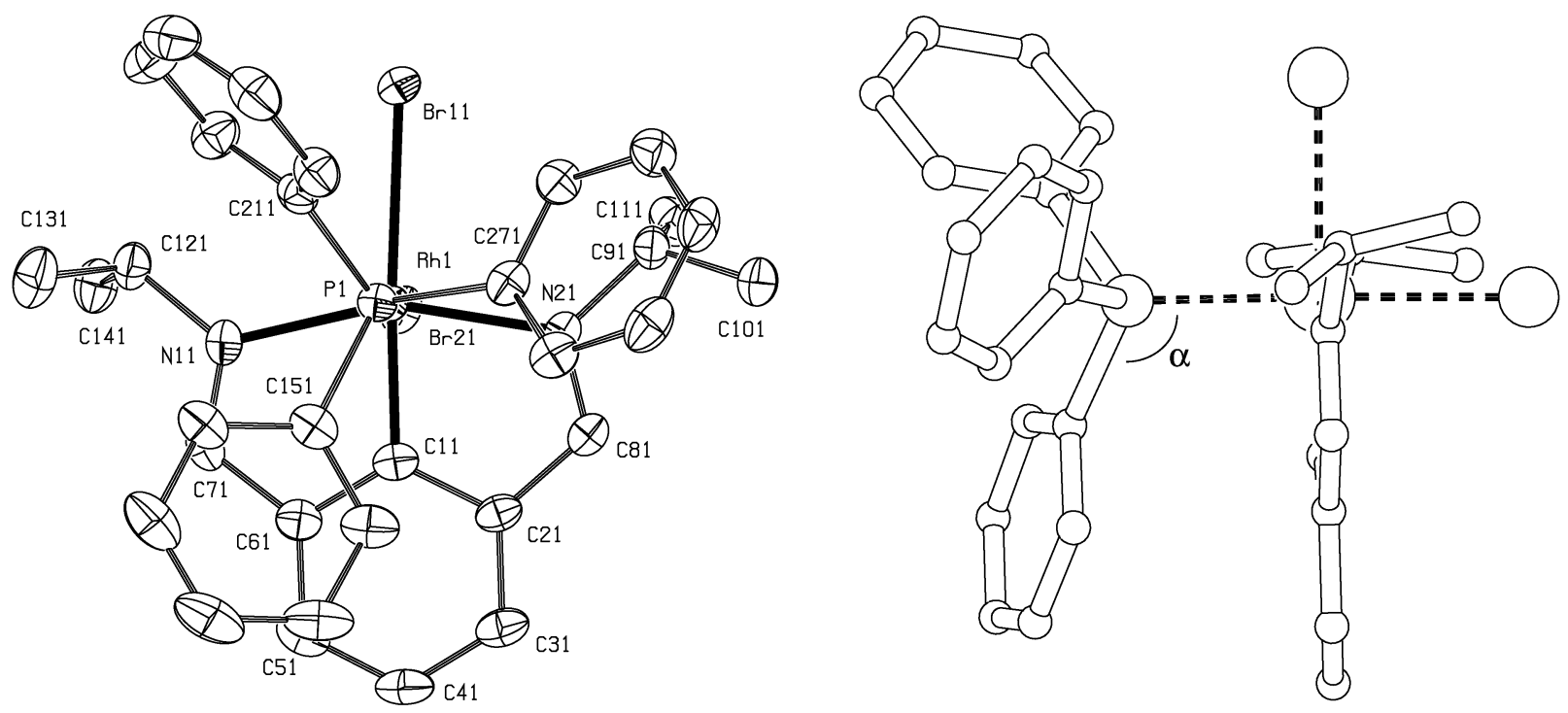

\section{Residue 2}
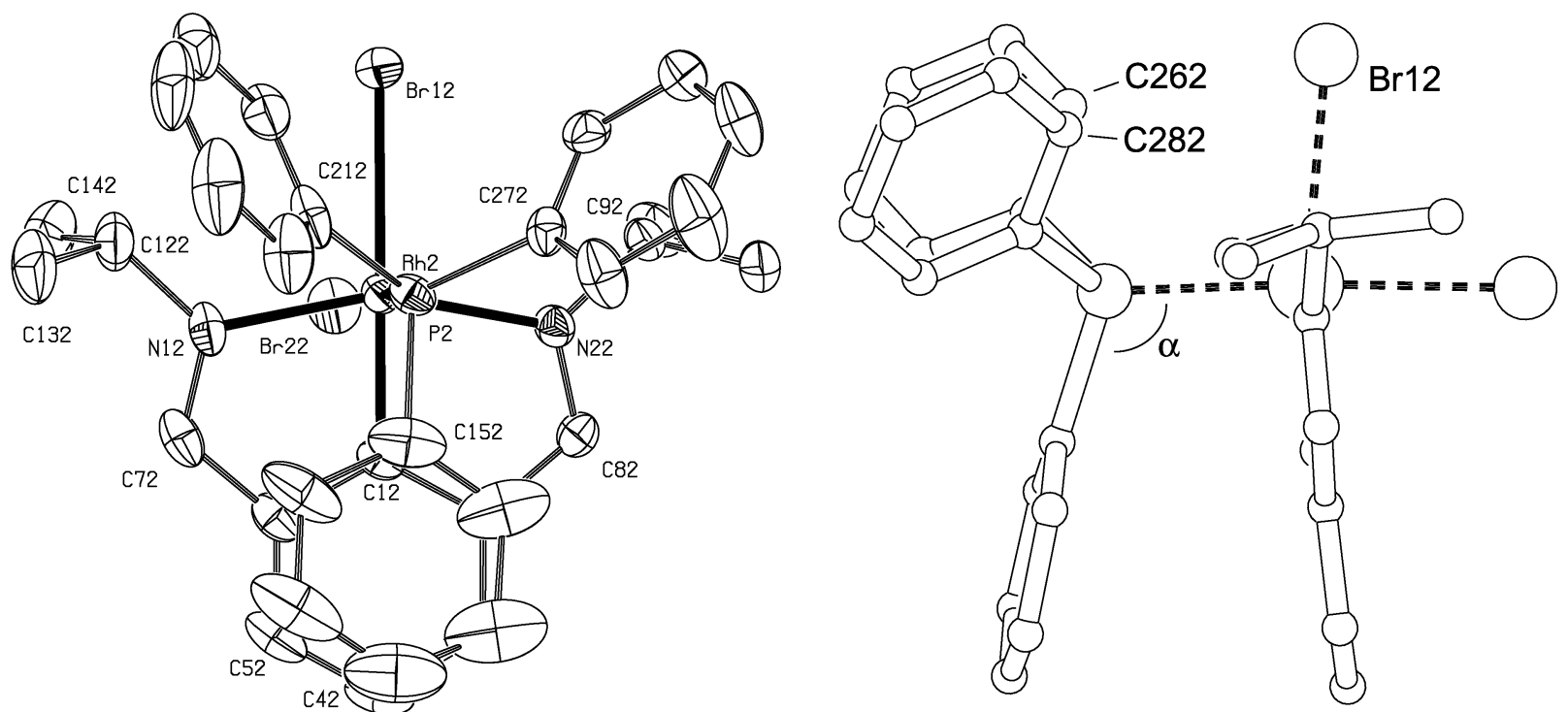

Figure 4. (left) Displacement ellipsoid plots of the two conformations of $\mathbf{1 3 \mathbf { b }}$ with ellipsoids drawn at the $50 \%$ probability level. (right) Views across the $\mathrm{N}(\mathrm{ln})-\mathrm{N}(2 \mathrm{n})$ line. Hydrogens are omitted for clarity.

methylzinc. For $\mathbf{1 5 b}, \mathrm{Rh}-\mathrm{C}_{\text {ipso }}$ gave a sharp signal with a ${ }^{1}\left({ }^{13} \mathrm{C},{ }^{103} \mathrm{Rh}\right)$ coupling of $30 \mathrm{~Hz}$, while the $\mathrm{Rh}-\mathrm{CH}_{3}$ signal was broadened (at $298 \mathrm{~K}, \mathrm{CDCl}_{3}, 126 \mathrm{MHz}$ ).

In the analogous transmetalation reaction of $\mathbf{7 c}-\mathbf{9 c}$ $(\mathrm{R}=$ tert-butyl) both bromide and chloride substitution took place, resulting in a 1:4 ratio of the rhodium(III) isophthalaldimine methyl chloride (16c) and the rhodium(III) isophthalaldimine methyll bromide (14c) compounds, respectively (Scheme 8). The latter (14c) could be obtained pure from a transmetalation reaction by starting from pure rhodium(III) isophthalaldimine dibromide 9c, as was supported by ${ }^{103}$ Rh NMR spectroscopy and an elemental analysis. The trend observed in the ${ }^{103} \mathrm{Rh}$ chemical shifts of the rhodium(III) isophthalaldimine methyl halide compounds $\mathbf{1 4 - 1 6}$ is $\mathrm{Cl}>\mathrm{Br}>$ $\mathrm{I}$ and follows the nephelauxetic series, as was found previously..$^{23}$ Compounds $\mathbf{1 4}$ and $\mathbf{1 5}$ are air stable in the solid state but decompose very slowly in solution to unidentified products. No reductive $\mathrm{C}_{\text {aryl }}-\mathrm{C}_{\text {methyl }}$ coupling was observed.

(a) X-ray Crystal Structure Determination of 14c. The molecular structure of $\mathbf{1 4 c}$ was determined by an X-ray crystal structure analysis. In the crystal of $\mathbf{1 4 c}$ there are two independent molecules present, which differ significantly in their conformations. These are depicted in Figure 5; selected bond lengths and angles are given in Table 6 . In both conformations, the fivecoordinate rhodium center has a coordination geometry which is between a trigonal bipyramid and square pyramid. For the first conformation, the distortion along the Berry pseudorotation coordinate, from a trigonal bipyramid toward a square pyramid, is $47.3 \%$; for the second conformation, this distortion is $52.8 \%$. The distortion from a square-pyramidal geometry is merely caused by the position of the bromide bel ow the squarepyramidal basal plane (defined by Rh, N(1), N(2), C(17), 
Table 5. Selected Bond Lengths $(\AA)$ and Angles (deg) for $13 b$

\begin{tabular}{|c|c|c|}
\hline & residue 1 & residue 2 \\
\hline $\begin{array}{l}\operatorname{Rh}(n)-\operatorname{Br}(1 n) \\
\operatorname{Rh}(n)-\operatorname{Br}(2 n) \\
\operatorname{Rh}(n)-P(n) \\
\operatorname{Rh}(n)-C(1 n) \\
\operatorname{Rh}(n)-N(1 n) \\
\operatorname{Rh}(n)-N(2 n) \\
N(1 n)-C(7 n) \\
N(2 n)-C(8 n)\end{array}$ & $\begin{array}{l}2.6545(3) \\
2.5311(3) \\
2.3169(6) \\
1.923(2) \\
2.104(2) \\
2.113(2) \\
1.297(3) \\
1.292(3)\end{array}$ & $\begin{array}{l}2.6450(3) \\
2.5260(3) \\
2.3155(6) \\
1.920(2) \\
2.0739(19) \\
2.1023(19) \\
1.301(3) \\
1.293(3)\end{array}$ \\
\hline $\begin{array}{l}\mathrm{N}(1 n)-\operatorname{Rh}(n)-\mathrm{N}(2 n) \\
\operatorname{Br}(2 n)-\operatorname{Rh}(n)-P(n) \\
\operatorname{Br}(1 n)-\operatorname{Rh}(n)-C(1 n) \\
\operatorname{Br}(1 n)-\operatorname{Rh}(n)-\operatorname{Br}(2 n) \\
\operatorname{P}(n)-\operatorname{Rh}(n)-C(1 n) \\
N(1 n)-\operatorname{Rh}(n)-C(1 n) \\
N(2 n)-\operatorname{Rh}(n)-C(1 n) \\
\operatorname{Br}(1 n)-\operatorname{Rh}(n)-N(1 n) \\
\operatorname{P}(n)-\operatorname{Rh}(n)-N(1 n) \\
\operatorname{Br}(2 n)-\operatorname{Rh}(n)-N(1 n) \\
\operatorname{Br}(2 n)-\operatorname{Rh}(n)-C(1 n) \\
\operatorname{Rh}(n)-P(n)-C(15 n) \\
C(7 n)-N(1 n)-C(12 n) \\
C(8 n)-N(2 n)-C(9 n)\end{array}$ & $\begin{array}{l}157.23(7) \\
177.962(18) \\
176.28(7) \\
90.496(9) \\
90.48(6) \\
78.57(9) \\
79.25(9) \\
104.83(5) \\
92.72(5) \\
85.46(5) \\
88.25(6) \\
113.36(8) \\
118.3(2) \\
119.5(2)\end{array}$ & $\begin{array}{l}158.37(8) \\
175.630(18) \\
170.53(7) \\
85.981(10) \\
92.11(7) \\
79.24(9) \\
79.24(9) \\
102.07(6) \\
89.94(6) \\
86.50(6) \\
84.74(7) \\
109.61(9) \\
120.2(2) \\
119.5(2)\end{array}$ \\
\hline
\end{tabular}

Scheme 8. Transmetalation of $7 c-9 c$ with $\mathrm{Me}_{2} \mathrm{Zn}$

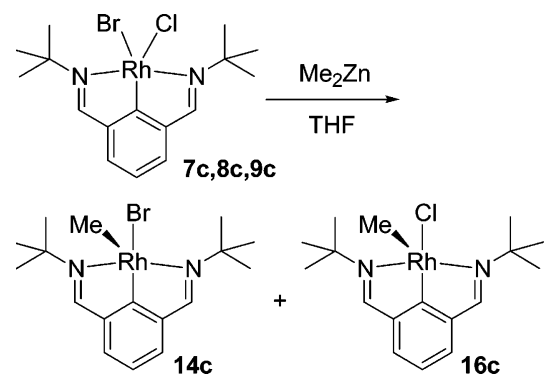

and $\operatorname{Br}(1)$ ); this positioning is dictated by the strong trans influence of the methyl group ${ }^{36}$ and steric hindrance between the imine-tert-butyl groups and the bromide. The latter can clearly be seen in the spacefilling models of the structures, depicted in Figure 5. A lifting of a halide out of the coordination plane was al so observed by Vrieze et al. in rhodium(I) chloride complexes of N-substituted 2,6-bis(imino)pyridines. ${ }^{37}$

The difference in geometry around the rhodium in both conformations, which is caused by packing effects, is clarified by the views along the $N(1)-N(2)$ lines, depicted in Figure 5. In both conformations the rhodiumbound methyl group is in a position cis to the aryl group; the $\mathrm{C}(1)-\mathrm{Rh}-\mathrm{C}(17)$ angle is $86.7(4)^{\circ}$ in the first conformation and $90.9(5)^{\circ}$ in the second conformation, respectively. The position of the bromide differs more in the two conformations; in the second conformation, the $\mathrm{C}(1)-\mathrm{Rh}-\mathrm{Br}$ angle is significantly smaller $\left(106.3(5)^{\circ}\right)$ compared to the first conformation $\left(112.5(4)^{\circ}\right)$. As a result, there is less steric hindrance between the $\mathrm{Br}$ and imine-tert-butyl groups, which could explain the shorter $\mathrm{Rh}-\mathrm{N}$ and $\mathrm{Rh}-\mathrm{Br}$ bond lengths in the second (2.041(13), 2.040(12), and 2.544(3) $\AA$, respectively) compared to the first conformation (2.067(11), 2.052(12), and 2.5694(19) $\AA$, respec-

(36) Anderson, G. K.; Cross, R. J . Chem. Soc. Rev. 1980, 9, 185215

(37) Haarman, H. F.; Ernsting, J . M.; Kranenburg, M.; Kooijman, H.; Veldman, N.; Spek, A. L.; van Leeuwen, P. W. N. M.; Vrieze, K. Organometallics 1997, 16, 887-900. tively). The smaller $\mathrm{C}(1)-\mathrm{Rh}-\mathrm{Br}$ angle in the second conformation also explains its slightly shorter $\mathrm{C}(1)-\mathrm{Rh}$ bond $(1.850(16) \AA)$ compared to the first conformation (1.86(12) $\AA$ ) as a result of the decreased mutual trans influence of the bromide and this carbon atom. The $\mathrm{Br}-\mathrm{Rh}-\mathrm{C}(17)$ angle shows an opposite trend and is $160.7(2)^{\circ}$ in the first conformation and $162.8(2)^{\circ}$ in the second conformation, respectively. The origin of the rather large difference in the $\mathrm{Rh}-\mathrm{C}(17)$ bond lengths, which are 2.018(10) $\AA$ in the first residue and 2.104(9) $\AA$ in the second residue, is currently not very well understood but may be due to distinctly different electronic energy surfaces (due to steric interferences between the rhodium-bound methyl group and the tertbutyl groups) in both residues.

The $\mathrm{Rh}-\mathrm{C}_{\text {aryl }}$ bond lengths are slightly shorter in $\mathbf{1 4 c}$ (1.850(16) and 1.860(12) $\AA$ ) compared to those in D $(1.898(2) \AA), \mathbf{9 b} \cdot \mathrm{H}_{2} \mathrm{O}(1.904(2) \AA)$, and $\mathbf{1 3 b}(1.920(2)$ and 1.923(2) $\AA$ ); the other bond lengths and angles do not differ significantly.

The geometry around the rhodium in $\mathbf{1 4 c}$ is quite different from that of other structures of rhodium methyl compounds containing $\left.[\mathrm{P}-\mathrm{C}-\mathrm{P}],{ }^{21,38}[\mathrm{P}-\mathrm{C}-\mathrm{N}]\right]^{39}$ $[\mathrm{P}-\mathrm{C}-\mathrm{O}],{ }^{40}$ and $[\mathrm{N}-\mathrm{C}-\mathrm{N}]^{12}$ ligands, in which the rhodium also is five-coordinated. In these structures the rhodium geometry is much more square pyramidal than in 14c. However, in those structures, the basal plane is defined by the aryl group, the two neutral donor groups, and the halide; the methyl group is in an apical position, trans to an empty coordination site (see Chart 2; E). In a related rhodium hydride chl oride [P-C-P] compound, the rhodium geometry is similar. ${ }^{9}$ However, if the rhodium in $\mathbf{1 4 c}$ is considered to be in (distorted) square pyramidal surroundings, the basal plane is defined by the methyl group, the two imines, and the bromide and the aryl group is in an apical position, trans to the empty site (see Chart 2; F). As described above, this difference is mainly caused by the steric hindrance between the bromide and the tert-butyl groups, because of which a coordination of the bromide in the $\mathrm{Rh}(1)$, $N(1), N(2), C(1)$ plane is impossible (see also Figure 5).

(b) ${ }^{{ }^{1}}$ H NOE Measurements on $\mathbf{1 4 b}$ and $15 \mathrm{~b}$. To investigate the rhodium geometry in the compounds $\mathbf{1 4 b}$ and $\mathbf{1 5 b}(\mathrm{R}=$ isopropyl) in relation to that in $\mathbf{1 4 c}(\mathrm{R}=$ tert-butyl), ${ }^{1} \mathrm{H}$ NOE measurements were performed on deoxygenized $\mathrm{CDCl}_{3}$ solutions $(500 \mathrm{MHz}, 313 \mathrm{~K})$. It was found that, in both $\mathbf{1 4 b}$ and $\mathbf{1 5 b}, \mathrm{Rh}-\mathrm{CH}_{3}$ has $\mathrm{NOE}$ interactions with the isopropyl methyls at low fre quency, while the interactions with the isopropyl methyls at high frequency are much weaker. The NOE interactions of the imine protons and the isopropyl methyls show the opposite trend. It was inferred that, in these cases ( $\mathrm{R}=$ isopropyl), unlike the situation for 14c, but in concert with other related structures published, ${ }^{12,21,38-40}$ the methyl group is in the apical position (see Chart 2; G). From the observed NOE interactions it was inferred that the isopropyl groups are positioned slightly obliquely. The halide is expected

(38) Liou, S.-Y.; Gozin, M.; Milstein, D. J . Am. Chem. Soc. 1995, 117, 9774-9775.

(39) Gandelman, M.; Vigalok, A.; Shimon, L. J. W.; Milstein, D. Organometallics 1997, 16, 3981-3986.

(40) Rybtchinski, B.; Oevers, S.; Montag, M.; Vigalok, A.; Rozenberg, H.; Mertin, J. M. L.; Milstein, D. J. Am. Chem. Soc. 2001, 123, 90649077. 


\section{Residue A}
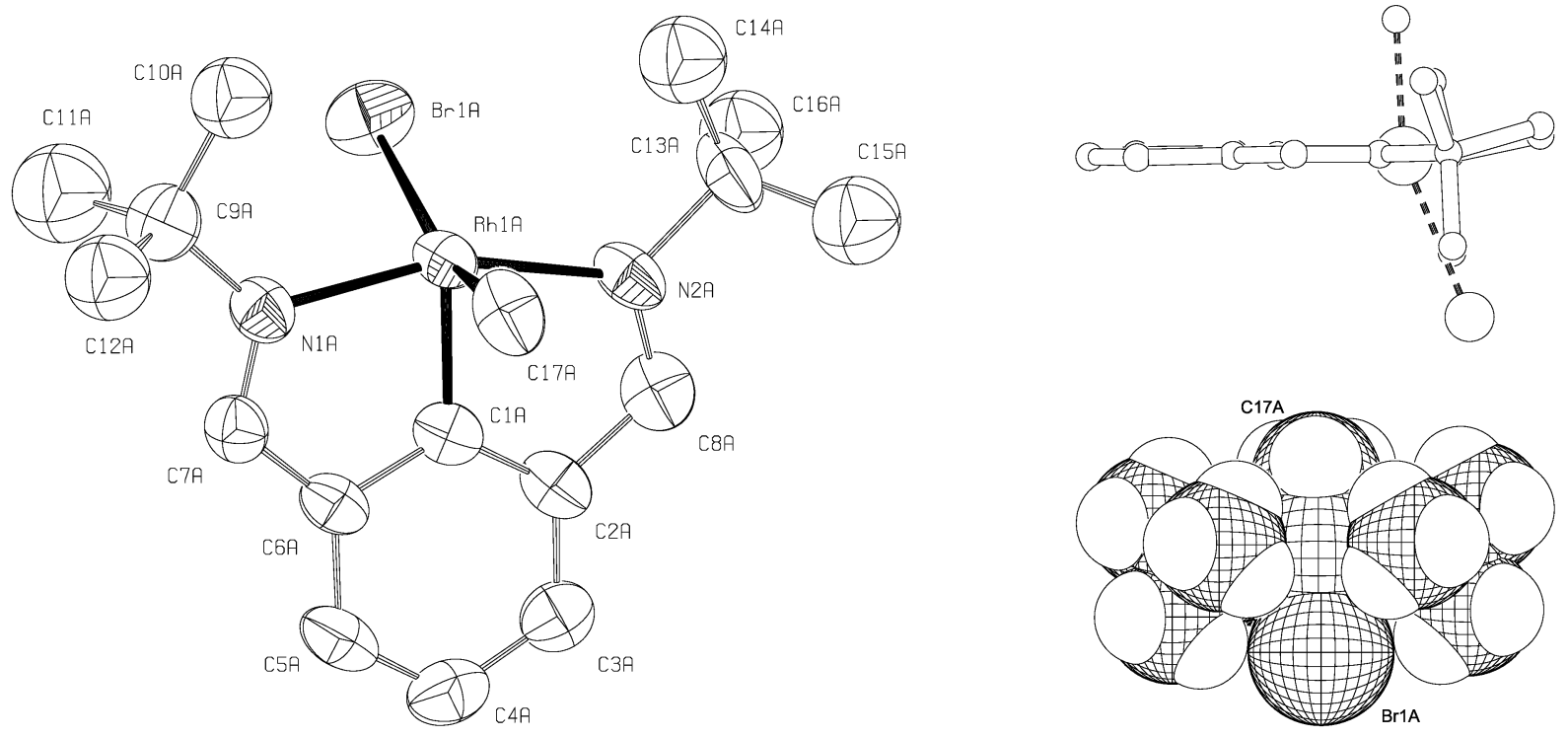

\section{Residue B}
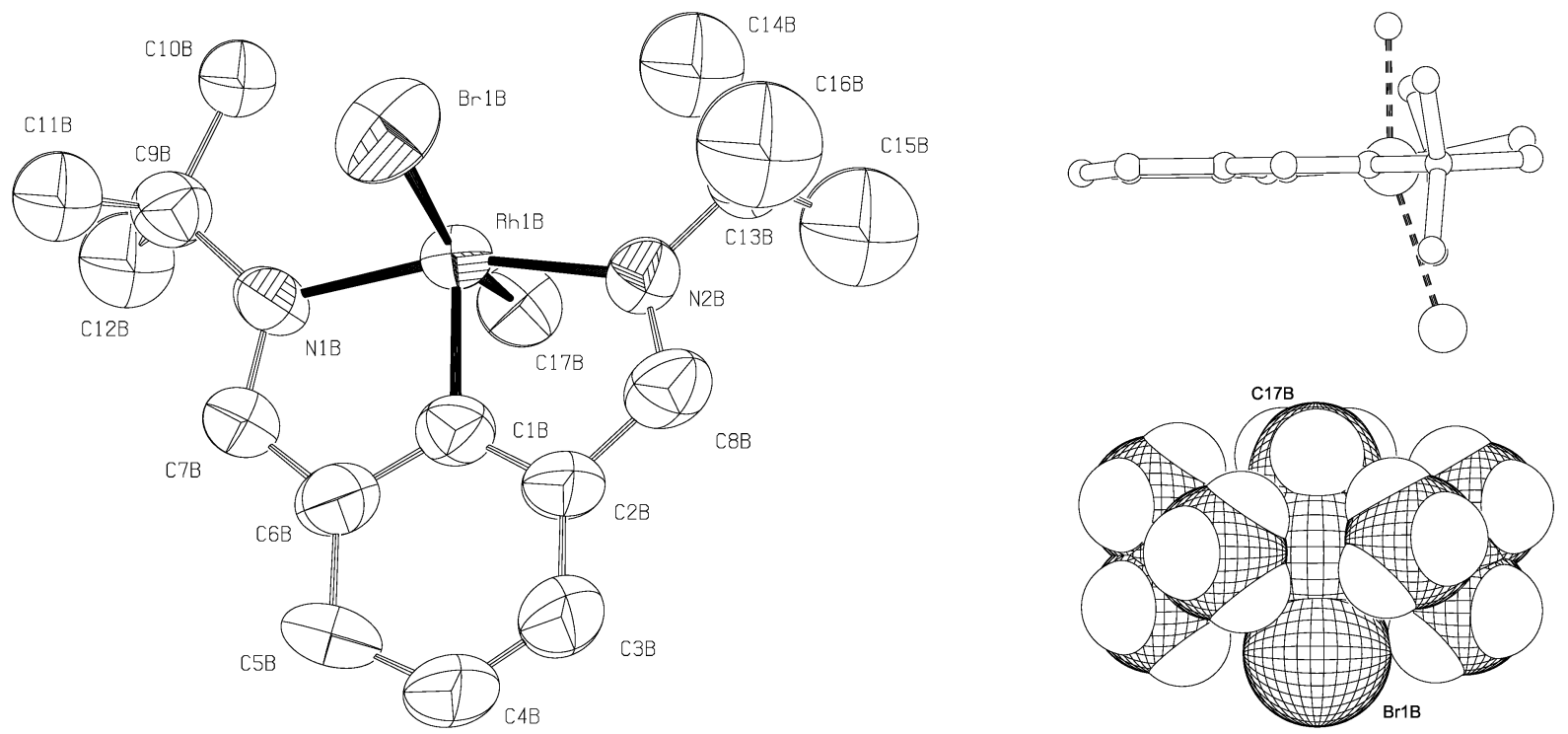

Figure 5. (left) Displacement ellipsoid plots of the two conformations of $\mathbf{1 4 c}$ with ellipsoids drawn at the $50 \%$ probability level. (top right) Views across the $\mathrm{N}(1 \mathrm{n})-\mathrm{N}(2 \mathrm{n})$ line. Hydrogens are omitted. (bottom right) Space-filling models, viewed along the $\mathrm{Rh}(1)-\mathrm{C}(1)$ bond, onto the tert-butyl moiety. Hydrogens are included.

to be in the basal plane in this cases (see Chart 2; G) because it suffers less hindrance from the isopropyl group (14b, 15b) compared to the tert-butyl group (14c).

\section{Concluding Remarks}

We have shown that the synthesis of rhodium(III) isophthalaldimine dihalide compounds via oxidative addition of a 2-bromo- or 2-iodoisophthalaldimine ligand to a suitable $\mathrm{Rh}^{\prime} \mathrm{Cl}$ precursor is a successful approach. Halide exchange of the formed mixtures gives a clean, single product in which the rhodium center is fivecoordinated, unless additional coordinating ligands are present; then, six-coordinate rhodium(III) compounds are obtained.

In the formed isophthalal dimine rhodium(III) dihalide compounds, the imine moieties coordinate strongly, as was illustrated by the addition of pyridine or $\mathrm{PPh}_{3}$ in excess, which gives coordination to rhodium center, but no substitution of the imine moieties was observed.

Transmetalation of the rhodium(III) isophthalaldimine dihalide compounds with $\mathrm{Me}_{2} \mathrm{Zn}$ successfully leads to the formation of rhodium(III) isophthalaldimine methyl halide compounds. These diorganorhodium compounds are stable and do not give rise to reductive $\mathrm{C}-\mathrm{C}$ coupling. This may be due to the strong electron donation of the imine moieties or to the fact that the $\mathrm{C}-\mathrm{Rh}-\mathrm{C}$ angle is rather large. Thus, for the isophthalal dimine ligand, as for the bis((dimethylamino)methyl)phenyl [N-C-N] and diphosphine [P-C-P] ligands, a stable rhodium methyl derivative can be prepared. The rhodium(III) isophthalal dimine methyl hal ide compounds (14 and 15) are very interesting entities in 
Table 6. Selected Bond Lengths $(\AA)$ and Angles (deg) for 14c

\begin{tabular}{lll}
\hline & residue A & residue B \\
\hline $\mathrm{Rh}(1)-\mathrm{Br}(1)$ & $2.5694(16)$ & $2.544(3)$ \\
$\mathrm{Rh}(1)-\mathrm{N}(1)$ & $2.067(11)$ & $2.041(13)$ \\
$\mathrm{Rh}(1)-\mathrm{N}(2)$ & $2.052(12)$ & $2.040(12)$ \\
$\mathrm{Rh}(1)-\mathrm{C}(1)$ & $1.860(12)$ & $1.850(16)$ \\
$\mathrm{Rh}(1)-\mathrm{C}(17)$ & $2.018(10)$ & $2.104(9)$ \\
$\mathrm{N}(1)-\mathrm{C}(7)$ & $1.281(17)$ & $1.307(19)$ \\
$\mathrm{N}(2)-\mathrm{C}(8)$ & $1.295(16)$ & $1.27(2)$ \\
$\mathrm{N}(1)-\mathrm{Rh}(1)-\mathrm{N}(2)$ & $160.3(4)$ & $161.8(5)$ \\
$\mathrm{Br}(1)-\mathrm{Rh}(1)-\mathrm{C}(1)$ & $112.5(4)$ & $106.3(5)$ \\
$\mathrm{Br}(1)-\mathrm{Rh}(1)-\mathrm{C}(17)$ & $160.7(2)$ & $162.8(2)$ \\
$\mathrm{C}(1)-\mathrm{Rh}(1)-\mathrm{C}(17)$ & $86.7(4)$ & $90.9(5)$ \\
$\mathrm{Br}(1)-\mathrm{Rh}(1)-\mathrm{N}(1)$ & $94.9(3)$ & $94.5(3)$ \\
$\mathrm{Br}(1)-\mathrm{Rh}(1)-\mathrm{N}(2)$ & $93.9(3)$ & $92.8(3)$ \\
$\mathrm{N}(1)-\mathrm{Rh}(1)-\mathrm{C}(1)$ & $80.6(5)$ & $81.7(6)$ \\
$\mathrm{N}(2)-\mathrm{Rh}(1)-\mathrm{C}(1)$ & $79.8(5)$ & $80.3(6)$ \\
$\mathrm{N}(1)-\mathrm{Rh}(1)-\mathrm{C}(17)$ & $88.0(4)$ & $89.0(4)$ \\
$\mathrm{N}(2)-\mathrm{Rh}(1)-\mathrm{C}(17)$ & $89.4(4)$ & $88.9(4)$
\end{tabular}

\section{Chart 2}

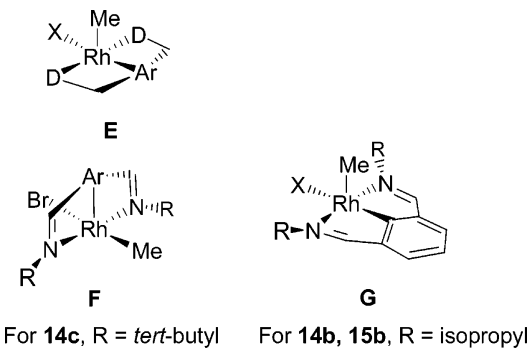

relation to $\mathrm{C}-\mathrm{C}$ bond activation processes. ${ }^{3}$ However, its microscopic reverse, the $\mathrm{C}-\mathrm{C}$ bond formation leading to o,o'-diiminotoluene derivatives, was not observed.

\section{Experimental Section}

All reactions involving air-sensitive compounds were carried out under a dinitrogen atmosphere using standard Schlenk techniques. Solvents were dried and distilled prior to use, according to standard methods. ${ }^{41}$ NMR measurements were performed on a Bruker AMX300/Narian Mercury300 spectrometer $\left({ }^{1} \mathrm{H}, 300.13 \mathrm{M} \mathrm{Hz} ;{ }^{13} \mathrm{C}, 75.47 \mathrm{M} \mathrm{Hz} ;{ }^{31} \mathrm{P}, 121.63 \mathrm{M} \mathrm{Hz}\right)$ and a Varian I nova500 spectrometer $\left({ }^{1} \mathrm{H}, 499.88 \mathrm{MHz} ;{ }^{13} \mathrm{C}\right.$, $125.70 \mathrm{M} \mathrm{Hz} ;{ }^{17} \mathrm{O}, 67.8 \mathrm{MHz}$ ) and Bruker DRX300 spectrometer $\left({ }^{103} \mathrm{Rh}, 9.48 \mathrm{MHz}\right) .{ }^{13} \mathrm{C}$ and ${ }^{31} \mathrm{P}$ NMR spectra were measured with ${ }^{1} \mathrm{H}$ decoupling, and ${ }^{103} \mathrm{Rh}$ NMR spectroscopy was measured by a gs-HMQC sequence at $298 \mathrm{~K} .42$ Positive chemical shifts $(\delta)$ are denoted for high-frequency shifts relative to a TMS reference $\left({ }^{1} \mathrm{H},{ }^{13} \mathrm{C}\right)$ and a $85 \% \mathrm{H}_{3} \mathrm{PO}_{4}$ reference $\left.{ }^{31} \mathrm{P}\right)$. Infrared spectroscopy was measured on a Biorad FTS-60A spectrometer from a solution in a $\mathrm{NaCl}$ cell. HRMS measurements were performed on a J EOL J MS SX/SX102A four-sector mass spectrometer, coupled to a J EOL MS-MP9021D/UPD system program. For fast atom bombardment (FAB) mass spectrometry, the samples were loaded in a matrix solution (3-nitrobenzyl alcohol) onto a stainless steel probe and bombarded with xenon atoms with an energy of $3 \mathrm{keV}$. During the high-resolution FAB-MS measurements a resolving power of 10000 (10\% valley definition) was used.

Materials. 2-Bromoisophthalaldehyde (3) has been described in previous papers. ${ }^{1,2}\left[\mathrm{RhCl}(\mathrm{coe})_{2}\right]_{2}{ }^{43}$ and $[\mathrm{RhCl}-$

(41) Perrin, D. D.; Armarego, L. F. Purification of Laboratory Chemicals; Pergamon Press: Oxford, U.K., 1998.

(42) Donkervoort, J . G.; Bühl, M.; Ernsting, J . M.; Elsevier, C. J . Eur. J . Inorg. Chem. 1999, 27-33.

(43) van der Ent, A.; Onderlingen, A. L. In Inorganic Syntheses; Angelici, R. J ., Ed.; Wiley: Toronto, Ontario, Canada, 1990; Vol. 28, p 90 . (ethene) $\left.)_{2}\right]_{2}{ }^{44}$ were prepared according to a literature procedure. All other starting materials were obtained from commercial sources and were used as received.

Bis(N-methyl)-2-bromoisophthalaldimine (1a). To a solution of $\mathbf{3}(0.5 \mathrm{~g}, 2.3 \mathrm{mmol})$ in $100 \mathrm{~mL}$ of THF were added methylammonium chloride $(5 \mathrm{~g}, 74 \mathrm{mmol}), \mathrm{Na}_{2} \mathrm{CO}_{3}(8 \mathrm{~g}, 75$ $\mathrm{mmol})$, and activated $3 \AA$ molecular sieves, and the reaction flask was closed with a $\mathrm{CaCl}_{2}$ tube. After the reaction mixture was stirred for a weekend, the reaction was complete (GC-MS). The reaction mixture was filtered, the volatiles were evaporated under reduced pressure, and the residue was dried

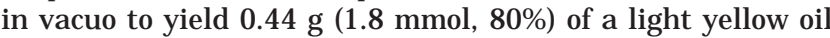
that solidified upon standing, which was identified by ${ }^{1 \mathrm{H}}$ and ${ }^{13} \mathrm{C}$ NMR spectroscopy as pure 1a. ${ }^{1} \mathrm{H}$ NMR $(200 \mathrm{MHz}$, $\left.\mathrm{CDCl}_{3}\right): \delta 8.74\left(\mathrm{dq},{ }^{4} \mathrm{\textrm {HH }}(\mathrm{Me})=1.7 \mathrm{~Hz},{ }^{5} \mathrm{HH}(\operatorname{aryl})=0.7 \mathrm{~Hz}\right.$, $2 \mathrm{H} ; \mathrm{HC}=\mathrm{N}), 7.99\left(\mathrm{~d}, 3 \mathrm{~J}_{\mathrm{Hн}}=7.7 \mathrm{~Hz}, 2 \mathrm{H}\right), 7.36\left(\mathrm{tt}, 3^{3} \mathrm{HH}=7.7\right.$ $\mathrm{Hz}, 5 \mathrm{~J} \mathrm{HH}=0.7 \mathrm{~Hz}, 1 \mathrm{H}), 3.57\left(\mathrm{~d},{ }^{4} \mathrm{HH}=1.7 \mathrm{~Hz}, 6 \mathrm{H}\right) .{ }^{13} \mathrm{C} \mathrm{NMR}$ $\left(126 \mathrm{M} \mathrm{Hz} \mathrm{CDCl}_{3}\right): \delta 161.6(\mathrm{C}=\mathrm{N}), 135.6(\mathrm{C}), 130.8(\mathrm{CH}), 127.8$ $(\mathrm{CH}), 126.9(\mathrm{C}-\mathrm{Br}) 48.6\left(\mathrm{CH}_{3}\right)$. GC-MS (m/z (relative intensity)): $240\left(\mathrm{M}\left({ }^{81} \mathrm{Br}\right)^{+}, 57\right), 240\left(\mathrm{M}\left({ }^{79} \mathrm{Br}\right)^{+}, 58\right), 196([\mathrm{M}-$ $\left.\mathrm{MeC}=\mathrm{NH}]^{+}, 9\right), 42(\mathrm{MeC}=\mathrm{NH}, 100)$.

Bis(N-isopropyl)-2-bromoisophthalaldimine (1b). To a solution of $3(1.0 \mathrm{~g}, 4.7 \mathrm{mmol})$ and isopropylamine $(2.4 \mathrm{~mL}$, $1.66 \mathrm{~g}, 28 \mathrm{mmol}, 3$ equiv) in THF (50 mL) was added activated $3 \AA$ molecular sieves, and the mixture was refluxed for $3 \mathrm{~h}$. GC-MS analysis showed complete conversion of 3. After filtration and extraction of the residue with THF, the solvent

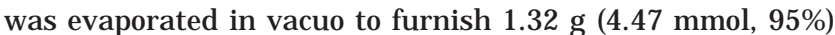
of a yellow solid which was identified by ${ }^{1} \mathrm{H}$ and ${ }^{13} \mathrm{C} N M R$ spectroscopy as pure 1b. ${ }^{1} \mathrm{H}$ NMR $\left(300 \mathrm{MHz} \mathrm{CDCl}_{3}\right): \delta 8.74$ $(\mathrm{s}, 2 \mathrm{H} ; \mathrm{HC}=\mathrm{N}), 8.02\left(\mathrm{~d}, 3_{\mathrm{HH}}=7.6 \mathrm{~Hz}, 2 \mathrm{H}\right), 7.34\left(\mathrm{t}, 3^{3} \mathrm{HH}_{\mathrm{H}}=7.6\right.$ $\mathrm{Hz}, 1 \mathrm{H}$ ), 3.65 (septet, ${ }^{3} \mathrm{H} \mathrm{HH}=6.3 \mathrm{~Hz}, 2 \mathrm{H} ; \mathrm{CH}_{3} \mathrm{CHCH}_{3}$ ), 1.28 $\left(d, 3_{\mathrm{HH}}=6.3 \mathrm{~Hz}, 12 \mathrm{H} ; \mathrm{CH}_{3} \mathrm{CHCH}_{3}\right) .{ }^{13} \mathrm{C} \mathrm{NMR}(75 \mathrm{MHz}$, $\left.\mathrm{CDCl}_{3}\right): \delta 157.1(\mathrm{C}=\mathrm{N}), 135.4(\mathrm{C}), 130.5(\mathrm{CH}), 127.3(\mathrm{CH})$, 126.5 (C-Br), $61.4\left(\mathrm{CH}_{3} \mathrm{CHCH}_{3}\right), 23.9\left(\mathrm{CH}_{3} \mathrm{CHCH}_{3}\right)$. HRMS $(\mathrm{El} ; \mathrm{m} / \mathrm{z})$ : calcd $\left([\mathrm{M}]^{+}, \mathrm{C}_{14} \mathrm{H}_{19}{ }^{79} \mathrm{BrN}_{2}\right)$ 294.0732, found 294.0734 .

Bis(N-tert-butyl)-2-bromoisophthalaldimine (1c). To a solution of 3 ( $1.0 \mathrm{~g}, 4.7 \mathrm{mmol})$ in $20 \mathrm{~mL}$ of THF were added tert-butylamine $(5 \mathrm{~mL}, 3.5 \mathrm{~g}, 48 \mathrm{mmol})$ and $3 \AA$ molecular sieves. The reaction mixture was stirred overnight at room temperature. ${ }^{1} \mathrm{H}$ NMR spectroscopic analysis showed full conversion, and the reaction mixture was filtered, the vol atiles were removed under reduced pressure, and the residue was dried in vacuo, which resulted in $1.34 \mathrm{~g}(4.15 \mathrm{mmol}, 88 \%)$ of a white solid which was identified by ${ }^{1} \mathrm{H}$ and ${ }^{13} \mathrm{C}$ NMR spectroscopy as pure 1c. ${ }^{1} \mathrm{H}$ NMR $\left(300 \mathrm{MHz}, \mathrm{CDCl}_{3}\right): \delta 8.70(\mathrm{~s}, 2 \mathrm{H}$; $\mathrm{HC}=\mathrm{N}), 8.00(\mathrm{~d}, 3 \mathrm{j} \mathrm{HH}=7.7 \mathrm{~Hz}, 2 \mathrm{H}), 7.35(\mathrm{t}, 3 \mathrm{j} \mathrm{Hн}=7.7 \mathrm{~Hz}$, $1 \mathrm{H}), 1.32(2,18 \mathrm{H}) .{ }^{13} \mathrm{C} \mathrm{NMR}\left(75 \mathrm{MHz} \mathrm{CDCl}_{3}\right): \delta 155.1$ $(\mathrm{C}=\mathrm{N}), 136.2(\mathrm{C}), 130.6(\mathrm{CH}), 127.8(\mathrm{CH}), 127.6(\mathrm{C}-\mathrm{Br})$ 58.4 (C), $29.9\left(\mathrm{CH}_{3}\right)$. HRMS (FAB; $\left.\mathrm{m} / \mathrm{z}\right)$ : calcd $\left([\mathrm{M}+\mathrm{H}]^{+}\right.$, $\mathrm{C}_{16} \mathrm{H}_{23} \mathrm{~N}_{2} \mathrm{Br}$ ) 323.112, found 323.1121 .

2,6-Bis([1,3]dioxolane)bromobenzene (4). The condensation of 2-bromoisophthalaldehyde $(7.0 \mathrm{~g}, 32.9 \mathrm{mmol})$ and ethylene glycol ( $30 \mathrm{~mL}$ ) was performed in $400 \mathrm{~mL}$ of toluene in a Dean-Stark setup and catalyzed by a small amount of p-toluenesulfonic acid. After the mixture was allowed to stand overnight, it was found by TLC analysis (silica gel $60,25 \%$ diethyl ether in hexanes) that the reaction was compl ete. M ost of the sol vent was evaporated, and $50 \mathrm{~mL}$ of diethyl ether and $50 \mathrm{~mL}$ of dichloromethane were added. The solution was washed three times with $15 \mathrm{~mL}$ of a $0.1 \mathrm{M} \mathrm{Na}_{2} \mathrm{CO}_{3}$ solution and subsequently with $20 \mathrm{~mL}$ of brine and dried on $\mathrm{MgSO}_{4}$. The solvents were evaporated, and the yellowish, sticky residue was recrystallized from methanol and air-dried to yield $6.47 \mathrm{~g} \mathrm{(21.5} \mathrm{mmol,} \mathrm{65 \% )} \mathrm{of} \mathrm{a} \mathrm{white} \mathrm{solid} \mathrm{that} \mathrm{was} \mathrm{identified}$ by ${ }^{1} \mathrm{H}$ and ${ }^{13} \mathrm{C}$ NMR spectroscopy as pure 4. ${ }^{1} \mathrm{H} N M R(300 \mathrm{MHz}$, $\left.\left.\mathrm{CDCl}_{3}\right): \delta 7.59(\mathrm{~d}, 3) \mathrm{HH}=7.5 \mathrm{~Hz}, 2 \mathrm{H}\right), 7.35\left(\mathrm{t}, 3 \mathrm{~J} \mathrm{HH}^{2}=7.5 \mathrm{~Hz}\right.$, $1 \mathrm{H}), 6.16(\mathrm{~s}, 2 \mathrm{H}), 4.15-4.00(\mathrm{~m}, 8 \mathrm{H}) .{ }^{13} \mathrm{C} N M R(75.5 \mathrm{MHz}$,

(44) Cramer, R. In Inorganic Syntheses; Angelici, R. J ., Ed.; Wiley: Toronto, Ontario, Canada, 1990; Vol. 28, p 86. 
$\left.\mathrm{CDCl}_{3}\right): \delta 137.7(\mathrm{C}), 128.8(\mathrm{CH}), 127.5(\mathrm{CH}), 102.8(\mathrm{CH}), 100.3$ $(\mathrm{C}-\mathrm{Br}), 65.7\left(\mathrm{CH}_{2}\right)$. HRMS (FAB; $\left.\mathrm{m} / \mathrm{z}\right)$ : calcd $\left([\mathrm{M}+\mathrm{H}]^{+}\right.$, $\mathrm{C}_{12} \mathrm{H}_{13} \mathrm{O}_{4}{ }^{79} \mathrm{Br}$ ) 301.0075. found 301.0039.

2,6-Bis([1,3]dioxolane)iodobenzene (5). A solution of 4 $(5.0 \mathrm{~g}, 16.6 \mathrm{mmol})$ in $20 \mathrm{~mL}$ of THF was cooled to $-60^{\circ} \mathrm{C}$, and $13.5 \mathrm{~mL}$ of a $1.6 \mathrm{M}$ solution of $\mathrm{n}-\mathrm{BuL} \mathrm{i}$ in hexanes $(21.6 \mathrm{mmol}$, 1.3 equiv) was added dropwise over $10 \mathrm{~min}$. After the addition, the reaction mixture was stirred at low temperature for 30 min, after which solid iodine $(5.52 \mathrm{~g}, 21.6 \mathrm{mmol})$ was added in small portions. During the addition, except for the last pieces, the iodine was consumed immediately. The brown reaction mixture was warmed to room temperature, and a solution of $\mathrm{Na}_{2} \mathrm{CO}_{3} \cdot 10 \mathrm{H}_{2} \mathrm{O}(8.5 \mathrm{~g}, 0.03 \mathrm{~mol})$ and $\mathrm{Na}_{2} \mathrm{~S}_{2} \mathrm{O}_{5}(6 \mathrm{~g}$, $0.03 \mathrm{~mol}$ ) in $300 \mathrm{~mL}$ of water was added. The THF was removed under reduced pressure, and the residue was extracted with $100 \mathrm{~mL}$ of dichloromethane. The organic layer was dried with $50 \mathrm{~mL}$ of brine and subsequently $\mathrm{MgSO}_{4}$. The solvents were evaporated, and the residue was recrystallized from methanol and air-dried to yield $3.72 \mathrm{~g} \mathrm{(11} \mathrm{mmol,} \mathrm{66 \% )} \mathrm{of}$ a white solid, which was identified by ${ }^{1} \mathrm{H}$ and ${ }^{13} \mathrm{C} N M R$ spectroscopy as pure 5. ${ }^{1} \mathrm{H}$ NMR $\left(300 \mathrm{MHz}_{1} \mathrm{CDCl}_{3}\right): \delta 7.54$ $\left.(\mathrm{d}, 3)_{\mathrm{Hн}}=7.5 \mathrm{~Hz}, 2 \mathrm{H}\right), 7.35\left(\mathrm{t}, 3_{\mathrm{HH}}=7.5 \mathrm{~Hz}, 1 \mathrm{H}\right), 6.05(\mathrm{~s}$, $2 \mathrm{H}), 4.16-4.03(\mathrm{~m}, 8 \mathrm{H}) .{ }^{13} \mathrm{C} \mathrm{NMR}\left(75.5 \mathrm{MHz} \mathrm{CDCl}_{3}\right): \delta 140.4$ (C), $128.8(\mathrm{CH}), 128.4(\mathrm{CH}), 106.9(\mathrm{CH}), 101.1(\mathrm{C}-\mathrm{I}), 65.7$ $\left(\mathrm{CH}_{2}\right)$. HRMS (FAB; $\left.\mathrm{m} / \mathrm{z}\right)$ calcd $\left([\mathrm{M}+\mathrm{H}]^{+}, \mathrm{C}_{12} \mathrm{H}_{13} \mathrm{O}_{4} \mathrm{I}\right)$ 348.9937, found 348.9937.

2-I odoisophthalaldehyde (6). To a solution of 5 (0.46 g, $1.3 \mathrm{mmol}$ ) in $25 \mathrm{~mL}$ of THF was added a solution of $1 \mathrm{~mL}$ of concentrated $\mathrm{H}_{2} \mathrm{SO}_{4}$ in $25 \mathrm{~mL}$ of water. The reaction mixture was heated to reflux for $1 \mathrm{~min}$ and then stirred at room temperature for $30 \mathrm{~min}$. The THF was removed under reduced pressure, upon which a preci pitate formed. The aqueous layer was made alkaline (pH 14) by the addition of an aqueous $\mathrm{KOH}$ solution. The precipitate was collected on a P3 glass filter, washed thoroughly with water, and dried overnight in a vacuum desiccator on $\mathrm{CaCl}_{2}$ to yield $0.32 \mathrm{~g}(1.2 \mathrm{mmol}, 93 \%)$ of a white solid, was which was identified by ${ }^{1} \mathrm{H}$ and ${ }^{13} \mathrm{C} N M R$ spectroscopy as pure 6. ${ }^{1} \mathrm{H}$ NMR $\left(500 \mathrm{MHz} \mathrm{CDCl}_{3}\right): \delta 10.32$ $(\mathrm{s}, 2 \mathrm{H}), 8.10\left(\mathrm{~d}, 3 \mathrm{~J}_{н н}=7.5 \mathrm{~Hz}, 2 \mathrm{H}\right), 7.57(\mathrm{t}, 3 \mathrm{3} \mathrm{нн}=7.5 \mathrm{~Hz}$, $1 \mathrm{H}) .{ }^{13} \mathrm{C} \mathrm{NMR}\left(125.7 \mathrm{MHz} \mathrm{CDCl}_{3}\right): \delta 195.3(\mathrm{C}=\mathrm{O}), 136.3(\mathrm{C})$, $135.9(\mathrm{CH}), 129.3(\mathrm{CH}), 106.4(\mathrm{C}-\mathrm{I}) . \mathrm{IR}\left(\mathrm{CDCl}_{3}\right): v_{\mathrm{C}=0} 1706$, $1682 \mathrm{~cm}^{-1}$. Anal. Calcd for $\mathrm{C}_{8} \mathrm{H}_{5} \mathrm{IO}_{2}: \mathrm{C}, 36.95 ; \mathrm{H}, 1.94$. Found: $\mathrm{C}, 36.83 ; \mathrm{H}, 2.04$. HRMS (FAB; $\mathrm{m} / \mathrm{z})$ : $\operatorname{calcd}\left([\mathrm{M}+\mathrm{H}]^{+}\right.$, $\mathrm{C}_{8} \mathrm{H}_{6} \mathrm{O}_{2} \mathrm{l}$ ) 260.9413, found 260.9412 .

Bis(N-isopropyl)-2-iodoisophthalaldimine (2b). To a solution of $6(0.20 \mathrm{~g}, 0.77 \mathrm{mmol})$ in $15 \mathrm{~mL}$ of isopropylamine activated was added $3 \AA$ molecular sieves. The reaction mixture was stored at room temperature for $3 \mathrm{~h}$ after which it was filtered over piece of cotton-wool and the residue was extracted with pentane. The volatiles were removed in vacuo to yield $0.23 \mathrm{~g}(0.66 \mathrm{mmol}, 86 \%)$ of a off-white sol id which was identified by ${ }^{1} \mathrm{H}$ and ${ }^{13} \mathrm{C}$ NMR spectroscopy as pure $\mathbf{2} \mathbf{b}$. ${ }^{1} \mathrm{H}$ NMR $\left(500 \mathrm{MHz} \mathrm{CDCl}_{3}\right): \delta 8.61(\mathrm{~s}, 2 \mathrm{H}), 7.95\left(\mathrm{~d}, 3 \mathrm{~J}_{\mathrm{нH}}=7.5\right.$ $\mathrm{Hz}, 2 \mathrm{H}$ ), $7.37\left(\mathrm{t}, 3 \mathrm{~J} \mathrm{HH}=7.5 \mathrm{~Hz}, 1 \mathrm{H}\right.$ ), 3.69 (septet, ${ }^{3} \mathrm{HH}=6 \mathrm{~Hz}$, $2 \mathrm{H}), 1.31\left(\mathrm{~d},{ }^{3} \mathrm{HH}=6 \mathrm{~Hz}, 12 \mathrm{H}\right) .{ }^{13} \mathrm{C} N M R(125.7 \mathrm{MHz}$, $\left.\mathrm{CDCl}_{3}\right): \delta 162.2(\mathrm{C}=\mathrm{N}), 138.4(\mathrm{C}), 131.1(\mathrm{CH}), 128.7(\mathrm{CH})$, $105.1(\mathrm{C}-\mathrm{I}), 61.6\left(\mathrm{CH}_{3} \mathrm{CHCH}_{3}\right), 24.4\left(\mathrm{CH}_{3} \mathrm{CHCH}_{3}\right)$. HRMS (FAB; $\mathrm{m} / \mathrm{z})$ calcd $\left([\mathrm{M}+\mathrm{H}]^{+}, \mathrm{C}_{14} \mathrm{H}_{20} \mathrm{~N}_{2} \mathrm{I}\right)$ 343.0671, found 343.0672. Anal. Calcd for $\mathrm{C}_{14} \mathrm{H}_{19} \mathrm{IN}_{2}$ : C, 49.14; H, 5.60; N, 8.19. Found: C, 49.01; H, 5.57; N, 8.12

Rhodium(III) $\kappa \mathbf{C}, \kappa \mathbf{N}, k \mathbf{N}^{\prime}-\mathbf{B}$ is(N-methyl)isophthalaldimin-2-yl Bromide/Chloride (7a-9a). To a solution of 1 a $(0.20 \mathrm{~g}, 0.84 \mathrm{mmol})$ in $25 \mathrm{~mL}$ of THF was added $\left[\mathrm{RhCl}(\mathrm{coe})_{2}\right]_{2}$ ( $286 \mathrm{mg}, 0.80 \mathrm{mmol}$ ), and the light brown solution was refluxed for $4 \mathrm{~h}$, during which time the product had partially precipitated. After the mixture was stirred overnight at room temperature, the THF was removed under reduced pressure, the residue was extracted with dichloromethane, and the extract was filtered over Celite. The dichloromethane was evaporated, and the residue was washed two times with diethyl ether and dried in vacuo to yield $0.26 \mathrm{~g}(0.69 \mathrm{mmol}, 86 \%)$ of a reddish brown solid, which was identified by ${ }^{1} \mathrm{H}$ and ${ }^{13} \mathrm{C} N M R$ spectroscopy as a clean mixture of compounds $\mathbf{7 a}-\mathbf{9 a}$. ${ }^{1} \mathrm{H} N \mathrm{NR}$ (300 M Hz, CD ${ }_{3} \mathrm{OD}$ ): $\delta 8.18,8.17,8.14$ (broad, $2 \mathrm{H} ; \mathrm{HC}=\mathrm{N}$ ), 7.55 $\left(d,{ }^{3} \mathrm{HH}_{\mathrm{H}}=7.5 \mathrm{~Hz}, 2 \mathrm{H}\right), 7.16,7.14,7.11\left(\mathrm{t},{ }^{3} \mathrm{H} \mathrm{H}=7.5 \mathrm{~Hz}, 1 \mathrm{H}\right)$, $3.61(6 \mathrm{H}) .{ }^{13} \mathrm{C} N M R\left(75.4 \mathrm{MHz}, \mathrm{CD}_{3} \mathrm{OD}\right): \delta 193.7$ ( $1 \mathrm{~J} \mathrm{CRh}=23.5$ $\mathrm{Hz}, \mathrm{C}-\mathrm{Rh}$, one component observed), $173.8(\mathrm{CH}=\mathrm{N}), 144.3$, $144.2,144.1(\mathrm{C}), 128.0,127.9,127.8(\mathrm{CH}), 122.6,122.4,122.2$ $(\mathrm{CH}), 46.8,46.7,46.5\left(\mathrm{CH}_{3}\right) .{ }^{103} \mathrm{Rh} N M R\left(\mathrm{CD}_{3} \mathrm{OD}\right): \delta 3888$, 3733, 3569.

Rhodium(III) $\kappa \mathbf{C}, k \mathbf{N}, k \mathbf{N}^{\prime}-\mathbf{B i s}(\mathbf{N}$-isopropyl)isophthalaldimin-2-yl Bromide/Chloride (7b-9b). To a solution of $\mathbf{1 b}$ (138 mg, $0.47 \mathrm{mmol})$ in $20 \mathrm{~mL}$ of THF was added [RhCl (coe $\left.)_{2}\right]_{2}$ (140 mg, $0.39 \mathrm{mmol}$ ), and the light brown solution was stirred at $60{ }^{\circ} \mathrm{C}$ for $3 \mathrm{~h}$. The resulting deep brown solution was concentrated and filtered over Celite. The THF was removed under reduced pressure, and the residue was dried in vacuo, washed three times with pentane, and dried in vacuo to yield $154 \mathrm{mg}(0.35 \mathrm{mmol}, 91 \%)$ of a reddish brown compound, which was identified by ${ }^{1} \mathrm{H}$ and ${ }^{13} \mathrm{C}$ NMR spectroscopy as a clean mixture of compounds $\mathbf{7 b}-\mathbf{9 b}$. ${ }^{1} \mathrm{H}$ NMR $\left(500 \mathrm{MHz}, \mathrm{CD}_{3} \mathrm{OD}\right)$ : $\delta 8.32,8.30,8.27(\mathrm{~d}, 3 \mathrm{~J} \mathrm{HRh}=3 \mathrm{~Hz}, 2 \mathrm{H} ; \mathrm{HC}=\mathrm{N}), 7.64,7.63$, $7.62(\mathrm{~d}, 3 \mathrm{3} \mathrm{HH}=8 \mathrm{~Hz}, 2 \mathrm{H}), 7.23,7.20,7.18\left(\mathrm{t}, 3^{3} \mathrm{HH}=8 \mathrm{~Hz}, 1 \mathrm{H}\right)$, $4.15-4.10(2 \mathrm{H}), 1.52,1.51,1.50(\mathrm{~d}, 12 \mathrm{H}) .{ }^{13} \mathrm{C}$ NMR $(126 \mathrm{MHz}$, $\mathrm{CD}_{3} \mathrm{OD}$ ): $\delta$ 193.9, 193.1, 192.3 ( ${ }^{1} \mathrm{~J} \mathrm{CRh}=23.6 \mathrm{~Hz}, \mathrm{C}-\mathrm{Rh}$ ), 170.4 $(\mathrm{CH}=\mathrm{N}), 144.4,144.3,144.2(\mathrm{C}), 128.1,128.0,127.9(\mathrm{CH})$, 122.4, 122.2, $122.0(\mathrm{CH}), 60.8\left(\mathrm{CH}_{3} \mathrm{CHCH}_{3}\right), 22.5,22.3,22.2$ $22.0\left(\mathrm{CH}_{3} \mathrm{CHCH}_{3}\right) .{ }^{103} \mathrm{Rh} \mathrm{NMR}\left(\mathrm{CD}_{3} \mathrm{OD}\right): \delta 4185,4027,3862$. HRMS (FAB; m/z): calcd ([M $\left.]^{+}, \mathrm{C}_{14} \mathrm{H}_{19} \mathrm{~N}_{2}{ }^{37} \mathrm{Cl}{ }^{79} \mathrm{BrRh}\right) 433.9453$, found 433.9430. Single crystals suitable for an X-ray crystal structure analysis were obtained by slow cooling of a concentrated THF solution.

Rhodium(III) $k \mathbf{C}, k \mathbf{N}, k \mathbf{N}^{\prime}-\mathbf{B}$ is(N-isopropyl)isophthalaldimin-2-yl Bromide/Chloride Pyridine-d ${ }_{5}$. To a suspension of $\mathbf{7 b}-\mathbf{9 b}$ in $\mathrm{CDCl}_{3}$ in a NMR tube was added an excess of pyridine- $d_{5}$; immediately dissolution and quantitative conversion to the pyridine- $d_{5}$ adducts were observed, as was concluded from the ${ }^{1} \mathrm{H}$ and ${ }^{103} \mathrm{Rh}$ NMR spectra. ${ }^{1} \mathrm{H}$ NMR (500 $\mathrm{MHz}_{2} \mathrm{CDCl}_{3}$ /pyridine- $\mathrm{d}_{5}$ ): $\delta 8.17,8.14,8.12\left(\mathrm{~d},{ }^{3} \mathrm{HRh}=3 \mathrm{~Hz}\right.$, $2 \mathrm{H} ; \mathrm{HC}=\mathrm{N}), 7.61,7.60,7.59(\mathrm{~d}, 2 \mathrm{H}), 7.20,7.19,7.17(\mathrm{t}$, $1 \mathrm{H}), 3.66-3.59(2 \mathrm{H}), 1.22-1.14(12 \mathrm{H}) .{ }^{13} \mathrm{C} N M R(126 \mathrm{MHz}$, $\mathrm{CDCl}_{3} /$ pyridine- $\left.\mathrm{d}_{5}\right): \delta 197.6,196.3,195.0(1 \mathrm{~J} \mathrm{CRh}=20.2 \mathrm{~Hz}$, C-Rh), 170.6, 170.4, $170.3(\mathrm{CH}=\mathrm{N}), 151.7$ (pyridine), 144.0, $143.9,143.7$ (C), 137.3 (pyridine), 128.6, 128.6, $128.5(\mathrm{CH})$ 124,4 (pyridine), $123.0,122.8,122.7(\mathrm{CH}), 60.8\left(\mathrm{CH}_{3} \mathrm{CHCH}_{3}\right)$, 23.1, 22.9, 22.9, $22.7\left(\mathrm{CH}_{3} \mathrm{CHCH}_{3}\right) .{ }^{103} \mathrm{Rh} \mathrm{NMR}\left(\mathrm{CD}_{2} \mathrm{Cl}_{2} /\right.$ pyridine-d $\left.d_{5}\right): \delta 4133,4002,3847$.

Rhodium(III) $k \mathbf{C}, k \mathbf{N}, k \mathbf{N}^{\prime}-\mathbf{B i s}(\mathbf{N}$-tert-butyl)isophthalaldimin-2-yl Bromide/Chloride (7c-9c). The mixture of compounds $\mathbf{7 c}-\mathbf{9 c}$ was prepared analogously to $\mathbf{7 b}-\mathbf{9 b}$, from 1c (127.7 mg, $0.395 \mathrm{mmol})$ and $\left[\mathrm{RhCl}(\mathrm{coe})_{2}\right]_{2}$ (117.2 mg, 0.326 $\mathrm{mmol}$ ) in THF, overnight at $60^{\circ} \mathrm{C}$. The yield was $137.5 \mathrm{mg}$ $(0.298 \mathrm{mmol}, 91 \%)$ of a brown solid which was identified by ${ }^{1} \mathrm{H}$ and ${ }^{13} \mathrm{C}$ NMR spectroscopy as a dean mixture of compounds 7c-9c. ${ }^{1} \mathrm{H}$ NMR $\left(300 \mathrm{MHz}, \mathrm{CD}_{3} \mathrm{OD}\right): \delta 8.18(\mathrm{~m}, 2 \mathrm{H}), 7.63(\mathrm{~m}$, $2 \mathrm{H}), 7.18(\mathrm{~m}, 1 \mathrm{H}), 1.58,1.55,1.52(\mathrm{~s}, 18 \mathrm{H}) .{ }^{13} \mathrm{C} \mathrm{NMR}(75 \mathrm{MHz}$, $\left.\mathrm{CD}_{3} \mathrm{OD}\right): \delta 169.4,169.1,168.9(\mathrm{CH}=\mathrm{N}), 143.8,143.7,143.5$ (C), 128.5, 128.4, $128.4(\mathrm{CH}), 122.3,122.2,122.1(\mathrm{CH}), 63.8$, 63.8, $63.5\left(\mathrm{C}\left(\mathrm{CH}_{3}\right)_{3}\right), 29.5,29.2,28.7\left(\mathrm{C}_{\left.\left(\mathrm{CH}_{3}\right)_{3}\right)}(\mathrm{C}-\mathrm{Rh}\right.$ not resolved). ${ }^{103} \mathrm{Rh} N M R\left(\mathrm{CD}_{3} \mathrm{OD}\right): \delta 4587,4374,4107$

Rhodium(III) $\kappa \mathbf{C}, k \mathbf{N}, k \mathbf{N}^{\prime}-\mathbf{B}$ is(N-tert-butyl)isophthalaldimin-2-yl Bromide/Chloride Pyridine-d 5 . To a mixture of $\mathbf{7 c}-\mathbf{9 c}$ in $\mathrm{CDCl}_{3}$ in a NMR tube was added an excess of pyridine $\mathrm{d}_{5}$; immediately a quantitative conversion to the pyridine- $d_{5}$ adducts was observed, as was concluded from the ${ }^{1} \mathrm{H}$ and ${ }^{103} \mathrm{Rh} N M R$ spectra. ${ }^{1} \mathrm{H}$ NMR $(300 \mathrm{MHz}$, $\mathrm{CDCl}_{3} /$ pyridine- $\left.\mathrm{d}_{5}\right): \delta 8.00,7.98,7.95\left(\mathrm{~d},{ }^{3} \mathrm{JRh}_{\mathrm{HRh}}=3.6 \mathrm{~Hz}, 2 \mathrm{H}\right)$, $7.59(\mathrm{~d}, 3 \mathrm{JH}=7.8 \mathrm{~Hz}, 2 \mathrm{H}), 7.19(\mathrm{~m}, 1 \mathrm{H}), 1.15,1.13,1.12(\mathrm{~s}$, $18 \mathrm{H}) .{ }^{103} \mathrm{Rh} N \mathrm{NMR}\left(\mathrm{CDCl}_{3} /\right.$ pyridine-d $\left._{5}\right): \delta 4783,4637,4477$.

Rhodium(III) $k \mathbf{C}, k \mathbf{N}, k \mathbf{N}^{\prime}-\mathbf{B i s}(\mathbf{N}$-isopropyl)isophthalaldimin-2-yl Iodide/Chloride (7b, 10b, and 11b). The mixture of compounds $\mathbf{7 b} \mathbf{b} \mathbf{1 0 b}$, and $\mathbf{1 1 \mathbf { b }}$ was prepared, analogously to 
$\mathbf{7 b}, \mathbf{8 b}$, and $\mathbf{9 b}$, from $\mathbf{2 b}$ (146.8 $\mathrm{mg}, 0.429 \mathrm{mmol})$ and $[\mathrm{RhCl}-$ (coe) $]_{2}$ ( $135.1 \mathrm{mg}, 0.376 \mathrm{mmol}$ ) in THF, overnight at $60{ }^{\circ} \mathrm{C}$. The yield was $163.8 \mathrm{mg}(0.341 \mathrm{mmol}, 91 \%)$ of a brown solid, which was identified by ${ }^{1} \mathrm{H}$ and ${ }^{13} \mathrm{C}$ NMR spectroscopy as a clean mixture of the three compounds $\mathbf{7 b}, \mathbf{1 0 b}$, and $\mathbf{1 1 b} .{ }^{1} \mathrm{H}$ NMR (300 MHz, CD $\left.{ }_{3} \mathrm{OD}\right): \delta=8.27,8.20,8.12$ (d, 3) нRh $=3$ $\mathrm{Hz}, 2 \mathrm{H} ; \mathrm{HC}=\mathrm{N}), 7.59,7.58,7.56(\mathrm{~d}, 2 \mathrm{H}), 7.18,7.11,7.05(\mathrm{t}$, $1 \mathrm{H}), \quad 4.18-4.04(2 \mathrm{H}), \quad 1.54-1.44(\mathrm{~d}, 12 \mathrm{H}) .{ }^{103} \mathrm{Rh} N M R$ $\left(\mathrm{CD}_{3} \mathrm{OD}\right): \delta 4185,3674,3176$. HRMS (FAB; $\left.\mathrm{m} / \mathrm{z}\right)$ : calcd ([M $-\mathrm{Cl}^{+}, \mathrm{C}_{14} \mathrm{H}_{19} \mathrm{~N}_{2} \mathrm{RhI}$ ) 444.9648, found 444.9657 .

Rhodium(III) $\quad \kappa \mathbf{C}, \kappa \mathbf{N}, k \mathbf{N}^{\prime}-\mathbf{B}$ is(N-isopropyl)isophthalaldimin-2-yl Dibromide Hydrate $\left(\mathbf{9 b} \cdot \mathrm{H}_{2} \mathrm{O}\right)$. To a solution of $\mathbf{7 b}-\mathbf{9 b}(46.2 \mathrm{mg}, 0.106 \mathrm{mmol})$ in $20 \mathrm{~mL}$ of acetone was added $\mathrm{NaBr}(0.48 \mathrm{~g}, 4.7 \mathrm{mmol})$. The suspension was stirred overnight, after which the acetone was removed under reduced pressure. The residue was extracted three times with chloroform. The chloroform was removed under reduced pressure, and the residue was again subjected to a similar reaction with $\mathrm{NaBr}$ $(0.41 \mathrm{~g}, 4.0 \mathrm{mmol})$. The resulting chloroform solution was concentrated to a few milliliters and was left in air for 3 days, at which point the product precipitated as $29.3 \mathrm{mg}(0.059$ $\mathrm{mmol}, 56 \%$ ) of red crystalss, which were identified by ${ }^{1} \mathrm{H}$ and ${ }^{13} \mathrm{C}$ NMR spectroscopy as pure $\mathbf{9 b} \cdot \mathrm{H}_{2} \mathrm{O}$. ${ }^{1} \mathrm{H}$ NMR $(300 \mathrm{MHz}$, $\left.\mathrm{CD}_{3} \mathrm{OD}\right): \delta 8.32\left(\mathrm{~d},{ }^{3} \mathrm{HRh}_{\mathrm{HRh}}=3.3 \mathrm{~Hz}, 2 \mathrm{H} ; \mathrm{HC}=\mathrm{N}\right), 7.57\left(\mathrm{~d},{ }^{3} \mathrm{HH}\right.$ $=7.5 \mathrm{~Hz}, 2 \mathrm{H}$ ), $7.12(\mathrm{t}, 3 \mathrm{~J} \mathrm{HH}=7.5 \mathrm{~Hz}, 1 \mathrm{H}), 4.10$ (septet, 3) $\mathrm{HH}$ $=6.5 \mathrm{~Hz}, 2 \mathrm{H}), 1.47\left(\mathrm{~d},{ }^{3} \mathrm{Hн}=6.5 \mathrm{~Hz}, 12 \mathrm{H}\right) .{ }^{13} \mathrm{C}$ NMR $(75.4$ $\mathrm{MHz}, \mathrm{CD}_{3} \mathrm{OD}$ ): $\delta 192.3$ ( ${ }^{1} \mathrm{~J} \mathrm{CRh}=23.6 \mathrm{~Hz}, \mathrm{C}-\mathrm{Rh}$ ), 170.5 $(\mathrm{CH}=\mathrm{N}), 144.5(\mathrm{C}), 128.0(\mathrm{CH}), 122.1(\mathrm{CH}), 60.9\left(\mathrm{CH}_{3} \mathrm{CHCH}_{3}\right)$, $22.6\left(\mathrm{CH}_{3} \mathrm{CHCH}_{3}\right) .{ }^{103} \mathrm{Rh} N M R\left(\mathrm{CDCl}_{3}\right): \delta 3627 .{ }^{103} \mathrm{Rh} \mathrm{NMR}$ $\left(\mathrm{CD}_{3} \mathrm{OD}\right): \delta$ 3860. HRMS (FAB; $\left.\mathrm{m} / \mathrm{z}\right)$ : calcd $\left(\left[\mathrm{M}-\mathrm{H}_{2} \mathrm{O}\right]^{+}\right.$, $\left.\mathrm{C}_{14} \mathrm{H}_{19} \mathrm{~N}_{2}{ }^{79} \mathrm{Br}^{81} \mathrm{BrRh}\right) 477.8950$, found 477.8992. Anal. Calcd for $\mathrm{C}_{24} \mathrm{H}_{21} \mathrm{Br}_{2} \mathrm{~N}_{2} \mathrm{ORh}: \mathrm{C}, 33.90 ; \mathrm{H}, 4.27 ; \mathrm{N}, 5.65$. Found: $\mathrm{C}$, 33.84; $\mathrm{H}, 4.35 ; \mathrm{N}, 5.65$. The crystals obtained from the reaction were suitable for an X-ray structure determination.

Rhodium(III) $\kappa \mathbf{C}, k \mathbf{N}, k \mathbf{N}^{\prime}-\mathbf{B}$ is(N-tert-butyl)isophthalaldimin-2-yl Dibromide (9c). Compound 9c was prepared, analogously to $\mathbf{1 1 b}$, from a mixture of 7c-9c (43.1 mg, 0.0934 $\mathrm{mmol})$. After the second exchange the chloroform solution was evaporated to dryness to yiel d $45.8 \mathrm{mg}(0.0906 \mathrm{mmol}, 97 \%)$ of a brown solid, which was identified by ${ }^{1} \mathrm{H}$ and ${ }^{13} \mathrm{C} N M R$ spectroscopy as pure 9 c. ${ }^{1} \mathrm{H}$ NMR $\left(500 \mathrm{MHz}, \mathrm{CD}_{3} \mathrm{OD}\right): \delta 8.24$ $\left(\mathrm{d}, 3_{\mathrm{HRh}}=3.5 \mathrm{~Hz}, 2 \mathrm{H} ; \mathrm{HC}=\mathrm{N}\right), 7.66\left(\mathrm{~d}, 3_{\mathrm{HH}}=7.5 \mathrm{~Hz}, 2 \mathrm{H}\right)$, $7.12\left(\mathrm{t},{ }^{3} \mathrm{H} \mathrm{HH}=7.5 \mathrm{~Hz}, 1 \mathrm{H}\right), 1.62(\mathrm{~s}, 18 \mathrm{H}) .{ }^{13} \mathrm{C} \mathrm{NMR}(75.4 \mathrm{MHz}$, $\left.\mathrm{CD}_{3} \mathrm{OD}\right): \delta 186.2$ (1 $\left.\mathrm{CRh}=24 \mathrm{~Hz}, \mathrm{C}-\mathrm{Rh}\right), 169.8(\mathrm{CH}=\mathrm{N}), 143.9$

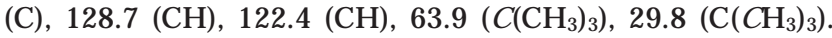
${ }^{103} \mathrm{Rh} N M R\left(\mathrm{CD}_{3} \mathrm{OD}\right): \delta 4115$. HRMS (FAB; $\left.\mathrm{m} / \mathrm{z}\right)$ : calcd ([M $\left.\left.\mathrm{H}_{2} \mathrm{O}\right]^{+}, \mathrm{C}_{16} \mathrm{H}_{23} \mathrm{~N}_{2}{ }^{79} \mathrm{Br}_{2} \mathrm{BrRh}\right)$ 503.9283, found 503.9290. Anal. Calcd for $\mathrm{C}_{16} \mathrm{H}_{23} \mathrm{Br}_{2} \mathrm{~N}_{2} \mathrm{Rh}$ : C, 37.97; $\mathrm{H}, 4.58 ; \mathrm{N}$, 5.54. Found: C, 38.03; $\mathrm{H}, 4.54 ; \mathrm{N}, 5.47$. Cal cd for $9 \mathrm{c} \cdot \mathrm{H}_{2} \mathrm{O}: \mathrm{C}, 36.67 ; \mathrm{H}, 4.81$; N, 5.35 .

Rhodium(III) $\kappa \mathbf{C}, k \mathbf{N}, k \mathbf{N}^{\prime}-\mathbf{B}$ is(N-isopropyl)isophthalaldimin-2-yl Diiodide (11b). Compound $\mathbf{1 1 b}$ was prepared, analogously to $\mathbf{9 b} \cdot \mathrm{H}_{2} \mathrm{O}$, from a mixture of $\mathbf{7 b}-\mathbf{9 b}(40.3 \mathrm{mg}$, $0.093 \mathrm{mmol}$ ) and $\mathrm{Nal}$. After the second exchange the chloroform solution was evaporated to dryness to yield $49.4 \mathrm{mg}$ $(0.0864 \mathrm{mmol}, 93 \%)$ of a brown solid, which was identified by ${ }^{1} \mathrm{H}$ and ${ }^{13} \mathrm{C}$ NMR spectroscopy as pure $\mathbf{1 l b}$. ${ }^{1} \mathrm{H}$ NMR $(300 \mathrm{MHz}$ $\left.\mathrm{CD}_{3} \mathrm{OD}\right): \delta 8.12(\mathrm{~d}, 3 \mathrm{~J}$ нRһ $=3.3 \mathrm{~Hz}, 2 \mathrm{H}), 7.56(\mathrm{~d}, 3 \mathrm{3}$ нн $=7.5$ $\mathrm{Hz}, 2 \mathrm{H}$ ), $7.05(\mathrm{t}, 3 \mathrm{~J} \mathrm{HH}=7.5 \mathrm{~Hz}, 1 \mathrm{H}), 4.16$ (septet, 3 $\mathrm{HHH}_{\mathrm{HH}}=$ $7 \mathrm{~Hz}, 2 \mathrm{H}), 1.53$ (d, 3 $\left.{ }^{3} \mathrm{Hн}=7 \mathrm{~Hz}, 12 \mathrm{H}\right) .{ }^{13} \mathrm{C} \mathrm{NMR}(75.4 \mathrm{MHz}$, $\left.\mathrm{CD}_{3} \mathrm{OD}\right): \delta 187.9(1 \mathrm{~J} \mathrm{CRh}=23.0 \mathrm{~Hz}, \mathrm{C}-\mathrm{Rh}), 170.9(\mathrm{CH}=\mathrm{N})$, $144.8(\mathrm{C}), 127.7(\mathrm{CH}), 121.5(\mathrm{CH}), 60.9\left(\mathrm{CH}_{3} \mathrm{CHCH}_{3}\right), 23.4$ $\left(\mathrm{CH}_{3} \mathrm{CHCH}_{3}\right) .{ }^{103} \mathrm{Rh} \mathrm{NMR}\left(\mathrm{CD}_{3} \mathrm{OD}\right): \delta 3175$. HRMS (FAB: $\mathrm{m} / \mathrm{z})$ : calcd $\left([\mathrm{M}+\mathrm{H}]^{+}, \mathrm{C}_{14} \mathrm{H}_{20} \mathrm{~N}_{2} \mathrm{Rhl}_{2}\right) 572.8771$, found 572.8764 . Anal. Calcd for $\mathrm{C}_{14} \mathrm{H}_{19}{ }_{2} \mathrm{~N}_{2} \mathrm{Rh}$ : C, 29.40; $\mathrm{H}, 3.35 ; \mathrm{N}, 4.90$. Found: C, 29.25; $\mathrm{H}, 3.42 ; \mathrm{N}, 4.80$. Calcd for $\mathbf{1 1 b} \cdot \mathrm{H}_{2} \mathrm{O}$ : C, 28.50; $\mathrm{H}, 3.59 ; \mathrm{N}, 4.75$.

Rhodium(III) $\kappa \mathbf{C}, k \mathbf{N}, \kappa \mathbf{N}^{\prime}-\mathbf{B}$ is(N-isopropyl)isophthalaldimin-2-yl Dibromide Pyridine-d $\mathbf{~}_{\mathbf{1}} \mathbf{( 2 b )}$. To a suspension of $\mathbf{9 b}$ in $\mathrm{CDCl}_{3}$ in a NMR tube was added an excess of pyridine $d_{5}$; immediately the quantitative formation of the pyridine- $d_{5}$ complex was observed, as was concluded from the ${ }^{1} \mathrm{H}$ and ${ }^{103} \mathrm{Rh} N \mathrm{NR}$ spectra. ${ }^{1} \mathrm{H}$ NMR (300 MHz, CDCl $3 /$ pyridine- $\mathrm{d}_{5}$ ): $\delta 8.12\left(\mathrm{~d}, 3 \mathrm{H}_{\mathrm{HRh}}=3 \mathrm{~Hz}, 2 \mathrm{H}\right), 7.63(\mathrm{~d}, 3 \mathrm{3} \mathrm{HH}=7.6 \mathrm{~Hz}, 2 \mathrm{H}), 7.23$ $\left(\mathrm{t}, 3^{3} \mathrm{HH}=7.6 \mathrm{~Hz}, 1 \mathrm{H}\right.$ ), 3.64 (septet, 3 ${ }_{\mathrm{H} \mathrm{HH}}=6.6 \mathrm{~Hz}, 2 \mathrm{H}$ ), 1.16 $\left(\mathrm{d},{ }^{3} \mathrm{H} \mathrm{HH}=7 \mathrm{~Hz}, 12 \mathrm{H}\right) .{ }^{103} \mathrm{Rh} \mathrm{NMR}\left(\mathrm{CDCl}_{3} /\right.$ pyridine $\left._{5}\right): \delta 3859$.

Rhodium(III) $K \mathbf{C}, k \mathbf{N}, k \mathbf{N}^{\prime}$-Bis(N-isopropyl)isophthalaldimin-2-yl Diiodide Pyridine-d $\mathbf{d}_{5}$. To a solution of $\mathbf{1 1 b}$ in $\mathrm{CD}_{2} \mathrm{Cl}_{2}$ in a NMR tube was added an excess of pyridine- $d_{5}$; immediately a quantitative conversion to the pyridine- $d_{5}$ complex was observed, as was concluded from the ${ }^{1} \mathrm{H}$ and ${ }^{103} \mathrm{Rh}$ NMR spectra. ${ }^{1} \mathrm{H}$ NMR $\left(300 \mathrm{MHz}, \mathrm{CD}_{2} \mathrm{Cl}_{2}\right): \delta 8.04(\mathrm{~d}$,

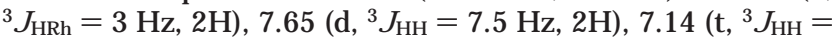
$7.5 \mathrm{~Hz}, 1 \mathrm{H}$ ), 3.75 (septet, 3 нн $\left._{\text {н }}=6 \mathrm{~Hz}, 2 \mathrm{H}\right), 1.28(\mathrm{~d}, 3 \mathrm{3}$ нн $=6$ $\mathrm{Hz}, 12 \mathrm{H}) .{ }^{103} \mathrm{Rh} N M R\left(\mathrm{CD}_{2} \mathrm{Cl}_{2}\right): \delta 3204$.

Rhodium(III) $k \mathbf{C}, k \mathbf{N}, k \mathbf{N}^{\prime}$-Bis(N-isopropyl)isophthalaldimin-2-yl Dibromide $\mathrm{PPh}_{3}$ Complex (13b). To a solution of $9 \mathbf{b}(53.3 \mathrm{mg}, 0.11 \mathrm{mmol})$ in $15 \mathrm{~mL}$ of THF was added triphenyl phosphine (151.0 mg, $0.85 \mathrm{mmol}$ ). The solution was refluxed for $10 \mathrm{~min}$, the reaction mixture was concentrated to a few milliliters, and the product was precipitated by the addition of pentane. The mother liquor was decanted, and the residue was washed three times with pentane and dried in vacuo to yield $60.8 \mathrm{mg}(0.082 \mathrm{mmol}, 74 \%)$ of a yellow solid, which was identified by ${ }^{1} \mathrm{H}$ and ${ }^{13} \mathrm{C} N \mathrm{NMR}$ spectroscopy as pure 13b. ${ }^{1} \mathrm{H}$ NMR $\left(500 \mathrm{MHz} \mathrm{CDCl}_{3}\right): \delta 7.92\left(\mathrm{br} \mathrm{d},{ }^{3} \mathrm{HRh}=\right.$ $\left.3.9 \mathrm{~Hz}, 3 \mathrm{~J}_{\mathrm{нн}}=1.2 \mathrm{~Hz}, 2 \mathrm{H} ; \mathrm{HC}=\mathrm{N}\right), 7.66-7.63(\mathrm{dd}, 6 \mathrm{H})$, 7.34-7.32 (br t, 3H), 7.23-7.18 (m, 8H ), $7.02\left(\mathrm{t},{ }^{3} \mathrm{~J} \mathrm{нн}=7.5\right.$ $\mathrm{Hz}, 1 \mathrm{H}$ ), 4.78 (septet, 3 ${ }_{\mathrm{Hн}}=6.6 \mathrm{~Hz}, 2 \mathrm{H}$ ), 1.59 (d, 3 ${ }_{\mathrm{Hн}}=6.6$ $\left.\mathrm{Hz}, 6 \mathrm{H} ; \mathrm{CH}_{3} \mathrm{CHCH}_{3}\right), 0.83\left(\mathrm{~d}, 3 \mathrm{3} \mathrm{HH}=6.6 \mathrm{~Hz}, 6 \mathrm{H} ; \mathrm{CH}_{3} \mathrm{CHCH}_{3}\right)$. ${ }^{13} \mathrm{C}$ NMR $\left(126 \mathrm{MHz} \mathrm{CDCl}_{3}\right): \delta 171(\mathrm{CH}=\mathrm{N}), 143.0(\mathrm{C}), 134.1$ $\left(\mathrm{CH}, \mathrm{J}_{\mathrm{CP}}=9.2 \mathrm{~Hz}\right), 131.1\left(\mathrm{CP}, \mathrm{J}_{\mathrm{CP}}=48.8 \mathrm{~Hz}\right), 130.4(\mathrm{CH}$, $\left.\mathrm{J}_{\mathrm{CP}}=2.3 \mathrm{~Hz}\right), 128.7(\mathrm{CH}), 128.2\left(\mathrm{CH}, \mathrm{J}_{\mathrm{CP}}=10.6 \mathrm{~Hz}\right), 122.6$ $(\mathrm{CH}), 59.4\left(\mathrm{CH}_{3} \mathrm{CHCH}_{3}\right), 26.5\left(\mathrm{CH}_{3} \mathrm{CHCH}_{3}\right), 22.6\left(\mathrm{CH}_{3} \mathrm{CHCH}_{3}\right)$. 31P NMR (121.5 MHz, $\left.\mathrm{CDCl}_{3}\right): \delta 21.65\left(\mathrm{~d},{ }^{1} \mathrm{PRh}=128 \mathrm{~Hz}\right)$. ${ }^{103} \mathrm{Rh}$ NMR $\left(\mathrm{CD}_{2} \mathrm{Cl}_{2}\right): \delta 2595\left(\mathrm{~d}\right.$, $\left.{ }^{1} \mathrm{RhP}=128 \mathrm{~Hz}\right)$. Due to the cocrystallization of solvents, no satisfactory analysis could be obtained. HRMS (FAB; $\mathrm{m} / \mathrm{z})$ : calcd $\left([\mathrm{M}+\mathrm{H}]^{+}\right.$, $\mathrm{C}_{32} \mathrm{H}_{35} \mathrm{~N}_{2}{ }^{79} \mathrm{Br}_{2} \mathrm{PRh}$ ) 738.9960, found 738.9913. Single crystals suitable for an X-ray crystal structure analysis were obtained by diffusion of pentane into a concentrated dichloromethane solution.

Rhodium(III) $k \mathbf{C}, k \mathbf{N}, k \mathbf{N}^{\prime}$-Bis(N-isopropyl)isophthalaldimin-2-yl Methyl Bromide (14b). To a solution of $\mathbf{9 b} \cdot \mathrm{H}_{2} \mathrm{O}$ $(60 \mathrm{mg}, 0.88 \mathrm{mmol})$ in $20 \mathrm{~mL}$ of THF at room temperature was added dimethylzinc $(2.5 \mathrm{~mL}$ of a $2 \mathrm{M}$ solution in toluene, $5 \mathrm{mmol}$ ). The reaction mixture turned from reddish brown to yellow, and after $50 \mathrm{~min}$, the reaction mixture was carefully quenched with water. Most of the THF was evaporated, 20 $\mathrm{mL}$ of dichloromethane was added, and the mixture was filtered over a cotton plug. After three extractions with $10 \mathrm{~mL}$ of dichloromethane, the organic layer was dried on $\mathrm{MgSO}_{4}$ and filtered and the solvents were evaporated in vacuo. The yellow residue was washed three times with $5 \mathrm{~mL}$ of pentane and dried in vacuo to yield $30.4 \mathrm{mg}(0.074 \mathrm{mmol}, 84 \%)$ of a yellow solid, which was identified by ${ }^{1} \mathrm{H}$ and ${ }^{13} \mathrm{C}$ NMR spectroscopy as pure 14b. ${ }^{1} \mathrm{H}$ NMR $\left(500 \mathrm{MHz} \mathrm{CDCl}_{3}, 296 \mathrm{~K}\right): \delta 8.31$ (d, 3) $\mathrm{HRh}=4.5 \mathrm{~Hz}, 2 \mathrm{H}), 7.46\left(\mathrm{~d},{ }^{3} \mathrm{~J} \mathrm{нH}=7.5 \mathrm{~Hz}, 2 \mathrm{H}\right), 7.06\left(\mathrm{t},{ }^{3} \mathrm{~J} \mathrm{нн}\right.$ $=7.5 \mathrm{~Hz}), 4.54(\mathrm{bm}, 3 \mathrm{3} \mathrm{HH}=6 \mathrm{~Hz}, 2 \mathrm{H}), 1.50\left(\mathrm{~d}, 3 \mathrm{~J}_{\mathrm{HH}}=6 \mathrm{~Hz}\right.$, $6 \mathrm{H}), 1.40\left(\mathrm{~d},{ }^{3} \mathrm{HH}=6 \mathrm{~Hz}, 6 \mathrm{H}\right), 0.05$ (bs, 3H). ${ }^{13} \mathrm{C}$ NMR $(125.7$ $\mathrm{MHz} \mathrm{CDCl}_{3}, 313 \mathrm{~K}$ ): $\delta 200.0$ ( $\left.{ }^{1} \mathrm{CRh}=31 \mathrm{~Hz}, \mathrm{C}-\mathrm{Rh}\right), 166.6$ (broad, $\mathrm{C}=\mathrm{N}$ ), $143.1(\mathrm{C}), 126.9(\mathrm{CH}), 120.9(\mathrm{CH}), 59.7$ (broad, $\left.\mathrm{CH}_{3} \mathrm{CHCH}_{3}\right), 24.5$ (broad, $\left.\mathrm{CH}_{3} \mathrm{CHCH}_{3}\right), 22.4\left(\mathrm{CH}_{3} \mathrm{CHCH}_{3}\right), 1.2$ ( $\left.{ }^{1} \mathrm{CRh}=28 \mathrm{~Hz}, \mathrm{Rh}-\mathrm{CH}_{3}\right) \cdot{ }^{103} \mathrm{Rh} \mathrm{NMR}\left(\mathrm{CDCl}_{3}\right): \delta 2450$. HRMS (FAB; $\mathrm{m} / \mathrm{z})$ : calcd $\left([\mathrm{M}+\mathrm{H}]^{+}, \mathrm{C}_{15} \mathrm{H}_{23} \mathrm{~N}_{2} \mathrm{BrRh}\right)$ 413.0100, found 413.0106. When an analogous reaction was performed with a mixture of $\mathbf{7 b}-\mathbf{9 b}(\mathrm{Rh}-\mathrm{Cl} / \mathrm{Br}), \mathbf{1 4} \mathbf{b}$ was also formed; the yield in this case was $56 \%$.

Rhodium(III) $k \mathbf{C}, k \mathbf{N}, k \mathbf{N}^{\prime}-\mathbf{B i s}(\mathbf{N}$-isopropyl)isophthalaldimin-2-yl Methyl Iodide (15c). Compound 15c was pre pared, analogously to $\mathbf{1 4 b}$, from a mixture of $\mathbf{7 b}, \mathbf{1 0 b}$, and $\mathbf{1 1 b}$ $(67.0 \mathrm{mg}, 0.139 \mathrm{mmol})$ and dimethylzinc $(2 \mathrm{~mL}$ of a $2.0 \mathrm{M}$ 
Table 7. Crystal Data and Details of the Structure Determination of $D, 9 b \cdot \mathrm{H}_{2} \mathrm{O}, 13 \mathrm{~b}$, and $14 c$

\begin{tabular}{|c|c|c|c|c|}
\hline & D & $\mathbf{9 b} \cdot \mathrm{H}_{2} \mathrm{O}$ & 13b & $14 c$ \\
\hline formula & $\begin{array}{c}\mathrm{C}_{18} \mathrm{H}_{27} \mathrm{BrClN}_{2} \mathrm{ORh} . \\
1.5 \mathrm{C}_{4} \mathrm{H}_{8} \mathrm{O}\end{array}$ & $\mathrm{C}_{14} \mathrm{H}_{21} \mathrm{Br}_{2} \mathrm{~N}_{2} \mathrm{ORh}$ & $\begin{array}{l}\mathrm{C}_{32} \mathrm{H}_{34} \mathrm{Br}_{2} \mathrm{~N}_{2} \mathrm{PRh}+ \\
\text { disorder solv }\end{array}$ & $\mathrm{C}_{17} \mathrm{H}_{26} \mathrm{BrN}_{2} \mathrm{Rh}$ \\
\hline fw & 613.84 & 496.06 & $740.31^{1}$ & 441.21 \\
\hline cryst color & red & red & yellow & yellow \\
\hline temp $(\mathrm{K})$ & 150 & 150 & 150 & 293 \\
\hline cryst syst & monodinic & monoclinic & monodinic & orthorhombic \\
\hline space group & $\mathrm{P} 2_{1} / \mathrm{c}$ (No. 14) & C2/C (No. 15) & $\mathrm{P} 21 / \mathrm{c}$ (No. 14) & $\mathrm{P} 22_{1} 2_{1} 2_{1}$ (No. 19) \\
\hline cryst size (mm) & $0.50 \times 0.50 \times 0.30$ & $0.12 \times 0.09 \times 0.06$ & $0.42 \times 0.33 \times 0.21$ & $0.50 \times 0.20 \times 0.15$ \\
\hline$a(\AA)$ & $14.5951(1)$ & $17.9937(2)$ & $23.0455(1)$ & $9.8568(8)$ \\
\hline$b(\AA)$ & $11.4836(1)$ & $11.8451(2)$ & 13.4782(1) & $15.2410(10)$ \\
\hline$c(\AA)$ & $15.8397(1)$ & $8.8178(1)$ & $28.5576(2)$ & $25.541(4)$ \\
\hline$\beta$ (deg) & $91.5006(3)$ & $119.2738(7)$ & $121.8235(4)$ & 90 \\
\hline$V / \AA^{3}$ & $2653.89(3)$ & $1639.39(4)$ & $7536.91(9)$ & $3837.0(7)$ \\
\hline Z & 4 & 4 & 8 & 8 \\
\hline$D_{\text {calcd }}\left(\mathrm{g} / \mathrm{cm}^{3}\right)$ & 1.536 & 2.010 & $1.305^{\mathrm{a}}$ & 1.528 \\
\hline$\mu\left(\mathrm{mm}^{-1}\right)$ & 2.274 & 5.913 & $2.635^{a}$ & 9.589 \\
\hline$((\sin \theta) / \lambda)_{\max }\left(\AA^{-1}\right)$ & 0.65 & 0.65 & 0.65 & 0.626 \\
\hline abs cor & SortAV 52 & PLATON (MULABS)50 & PLATON (MULABS)50 & PLATON $^{50}(\psi \text { scan })^{53}$ \\
\hline transmissn range & $0.33-0.44$ & $0.58-0.61$ & $0.39-0.48$ & $0.730-0.930$ \\
\hline no. of measd/unique rflns & 46 778/6079 & 14 472/1879 & 97 859/17272 & $4486 / 4486$ \\
\hline no. of obsd rflns $(I>2.0 \sigma(I))$ & 5244 & 1705 & 13993 & 4008 \\
\hline no. of params & 303 & 135 & 693 & 319 \\
\hline no. of restraints & 46 & 0 & 0 & 0 \\
\hline R1 (obsd/all rflns) & $0.0292 / 0.0358$ & $0.0197 / 0.0231$ & $0.0299 / 0.0393$ & $0.053 / 0.053$ \\
\hline wR2 (obsd/all rflns) & $0.0767 / 0.0805^{\mathrm{b}}$ & $0.0456 / 0.0472^{c}$ & $0.0723 / 0.0747^{d}$ & $0.0630 / 0.0630^{e}$ \\
\hline GOF & 1.034 & 1.57 & 1.036 & 1.09 \\
\hline resid density (e/ $\left.\AA^{3}\right)$ & $-0.85<0.75$ & $-0.83<0.54$ & $-0.72<0.93$ & $-1.32<0.83$ \\
\hline
\end{tabular}

a Derived values do not contain the contribution of the disordered solvent. ${ }^{b} \mathrm{~W}=1 /\left[\sigma^{2}\left(\mathrm{~F}_{0}{ }^{2}\right)+(0.0375 \mathrm{P})^{2}+3.5403 \mathrm{P}\right]$, where $\mathrm{P}=\left(\mathrm{F}_{0}{ }^{2}+\right.$ $2 \mathrm{~F}_{c^{2}}{ }^{2} / 3 .{ }^{c} \mathrm{~W}=1 /\left[\sigma^{2}\left(\mathrm{~F}_{0}{ }^{2}\right)+(0.0202 \mathrm{P})^{2}+1.2914 \mathrm{P}\right]$, where $\mathrm{P}=\left(\mathrm{F}_{\mathrm{o}}{ }^{2}+2 \mathrm{~F}_{c^{2}}{ }^{2}\right) / 3 .{ }^{\mathrm{d}} \mathrm{W}=1 /\left[\sigma^{2}\left(\mathrm{~F}_{\mathrm{o}}{ }^{2}\right)+(0.0380 \mathrm{P})^{2}+2.0530 \mathrm{P}\right]$, where $\mathrm{P}=\left(\mathrm{F}_{0}{ }^{2}+\right.$ $\left.2 \mathrm{~F}_{c}^{2}\right) / 3 .{ }^{e} \mathrm{~W}=1 /\left[0.01 \sigma^{2}\left(\mathrm{~F}_{\mathrm{o}}\right)+0.01 /\left(\sigma\left(\mathrm{F}_{\mathrm{o}}\right)\right)+10\right]$.

solution in toluene, $4 \mathrm{mmol}$ ). The reaction mixture was quenched after $20 \mathrm{~min}$. The yield was $59.1 \mathrm{mg}$ of an orangeyellow solid. From ${ }^{1} \mathrm{H},{ }^{13} \mathrm{C}$, and ${ }^{103} \mathrm{Rh} N \mathrm{~N} R$ spectroscopy it was concluded that the product contained approximately $10 \%$ of compound $\mathbf{1 1 b}\left(\mathrm{RhI}_{2}\right)$. On the basis of a purity of $90 \%$, the yield was $83 \%$. ${ }^{1} \mathrm{H}$ NMR (300 MHz, $\mathrm{CD}_{2} \mathrm{Cl}_{2}$ ): $\delta 8.30$ (d, 3) $\mathrm{HRh}$ $=4 \mathrm{~Hz}, 2 \mathrm{H}), 7.48(\mathrm{~d}, 3 \mathrm{~J} \mathrm{Hн}=7.5 \mathrm{~Hz}, 2 \mathrm{H}), 7.09(\mathrm{t}, 3 \mathrm{~J} \mathrm{Hн}=$ $7.5 \mathrm{~Hz}$ ), 4.68 (broad, 2H), $1.49(\mathrm{~d}, 3 \mathrm{3}$ нн $=6 \mathrm{~Hz}, 6 \mathrm{H}), 1.35$ (d, 35 нн $=6 \mathrm{~Hz}, 6 \mathrm{H}), 0.03$ (bs, 3H). ${ }^{13} \mathrm{C} N M R\left(75 \mathrm{MHz}, \mathrm{CD}_{2} \mathrm{Cl}_{2}\right)$ : $\delta 203.6$ ( ${ }^{1} \mathrm{CRh}_{\mathrm{CR}}=30.0 \mathrm{~Hz}, \mathrm{C}-\mathrm{Rh}$ ), $166.5(\mathrm{C}=\mathrm{N}), 143.2(\mathrm{C})$, $126.9(\mathrm{CH}), 120.8(\mathrm{CH}), 60.1\left(\mathrm{CH}_{3} \mathrm{CHCH}_{3}\right), 24.4\left(\mathrm{CH}_{3} \mathrm{CHCH}_{3}\right)$ $22.3\left(\mathrm{CH}_{3} \mathrm{CHCH}_{3}\right), 4.8$ (very broad, $\left.\mathrm{Rh}-\mathrm{CH}_{3}\right) .{ }^{103} \mathrm{Rh} \mathrm{NMR}$ $\left(\mathrm{CD}_{2} \mathrm{Cl}_{2}\right): \delta$ 2388. HRMS (FAB; $\left.\mathrm{m} / \mathrm{z}\right)$ : calcd ([M $\left.-\mathrm{I}\right]^{+}$, $\mathrm{C}_{15} \mathrm{H}_{22} \mathrm{~N}_{2} \mathrm{Rh}$ ) 333.0838, found 333.0833.

Rhodium(III) $k \mathbf{C}, k \mathbf{N}, k \mathbf{N}^{\prime}-\mathbf{B i s}$ (N-tert-butyl)isophthalaldimin-2-yl Methyl Bromide/Chloride (14c). Analogous to the method for $\mathbf{1 4 b}$, a mixture of $\mathbf{7 c}-\mathbf{9 c}(55 \mathrm{mg}, 0.12 \mathrm{mmol})$ was reacted with $\mathrm{Me}_{2} \mathrm{Zn}$ ( $1 \mathrm{~mL}$ of a $2 \mathrm{M}$ solution in toluene, 2 $\mathrm{mmol}$ ). The reaction mixture turned from reddish brown to brown and was quenched after $1 \mathrm{~h}$. The yellowish brown residue was dissolved in a dichloromethane/chloroform mixture and the brown pollution was precipitated by the addition of pentane. The supernatant was filtered over Celite, and the solvents were removed in vacuo to yield $43.5 \mathrm{mg}$ of a yellow solid, which was identified as a mixture of two rhodium methyl compounds in a 1:4 ratio. The major product was characterized as the rhodium isophthalaldimine methyl bromide compound 14c $\left(\delta\left({ }^{103} \mathrm{Rh}\right)\left(\mathrm{CDCl}_{3}\right) 2369\right)$ and the minor product as the analogous rhodium isophthalaldiminemethyl chloride compound 16c $\left(\delta\left({ }^{103} \mathrm{Rh}\right)\left(\mathrm{CDCl}_{3}\right)\right.$ 2418). HRMS (FAB; $\left.\mathrm{m} / \mathrm{z}\right)$ : cal cd $\left([\mathrm{M}-\mathrm{X}]^{+}, \mathrm{C}_{17} \mathrm{H}_{26} \mathrm{~N}_{2} \mathrm{Rh}\right) 361.1151$, found 361.1125 .

Rhodium(III) $k \mathbf{C}, k \mathbf{N}, k \mathbf{N}^{\prime}$-Bis(N-tert-butyl)isophthalaldimin-2-yl Methyl Bromide (14c). Compound 14c was prepared, analogously to $\mathbf{1 4 b}$, from $\mathbf{9 c}(30.5 \mathrm{mg}, 0.060 \mathrm{mmol})$ and $\mathrm{Me}_{2} \mathrm{Zn}$ ( $2 \mathrm{~mL}$ of a $2 \mathrm{M}$ solution in toluene, $4 \mathrm{mmol}$ ). The reaction was quenched after $30 \mathrm{~min}$. The yield was $22.9 \mathrm{mg}$ $(0.052 \mathrm{mmol}, 86 \%)$ of a yellow crystalline solid, which was identified by ${ }^{1} \mathrm{H},{ }^{13} \mathrm{C}$, and ${ }^{103} \mathrm{Rh}$ NMR spectroscopy as pure $\mathbf{1 4 c}$. ${ }^{1} \mathrm{H}$ NMR $\left(500 \mathrm{MHz}, \mathrm{CD}_{2} \mathrm{Cl}_{2}\right): \delta 8.46\left(\mathrm{~d},{ }^{3} \mathrm{HRh}=5 \mathrm{~Hz}, 2 \mathrm{H}\right)$, $7.54\left(\mathrm{~d}, 3^{3} \mathrm{HH}=7.5 \mathrm{~Hz}, 2 \mathrm{H}\right), 7.17\left(\mathrm{t}, 3^{3} \mathrm{HH}=7.5 \mathrm{~Hz}\right), 1.67(\mathrm{~s}$,
$18 \mathrm{H}),-0.01\left(\mathrm{~d},{ }^{3} \mathrm{HRh}=2 \mathrm{~Hz}\right) .{ }^{13} \mathrm{C}$ NMR $\left(125.7 \mathrm{MHz}, \mathrm{CD}_{2} \mathrm{Cl}_{2}\right)$ : $\delta 189.5$ ( $\left.{ }^{1} \mathrm{~J} \mathrm{CRh}=37 \mathrm{~Hz}, \mathrm{C}-\mathrm{Rh}\right), 165.7\left({ }^{2} \mathrm{~J} \mathrm{CRh}=3 \mathrm{~Hz}, \mathrm{C}=\mathrm{N}\right.$ ), $141.4(\mathrm{C}), 127.5(\mathrm{CH}), 121.1(\mathrm{CH}), 61.9\left(\mathrm{C}\left(\mathrm{CH}_{3}\right)_{3}\right), 31.0\left(\mathrm{C}\left(\mathrm{CH}_{3}\right)_{3}\right)$, $2.0\left({ }^{1} \mathrm{JRh}=25.0 \mathrm{~Hz}\right) .{ }^{103} \mathrm{Rh} \mathrm{NMR}\left(\mathrm{CD}_{2} \mathrm{Cl}_{2}\right):$ 2373. Anal. Calcd for $\mathrm{C}_{17} \mathrm{H}_{26} \mathrm{BrN}_{2} \mathrm{Rh}$ : C, 46.28; $\mathrm{H}, 5.94 ; \mathrm{N}, 6.35$. Found: $\mathrm{C}, 46.37 ; \mathrm{H}, 6.13 ; \mathrm{N}, 6.27$. HRMS (FAB; $\mathrm{m} / \mathrm{z})$ : calcd $\left([\mathrm{M}+\mathrm{H}]^{+}\right.$, $\mathrm{C}_{17} \mathrm{H}_{27} \mathrm{~N}_{2} \mathrm{BrRh}$ ) 441.0413, found 441.0403 .

Crystal Structure Determinations. Data collection and unit cell determination were carried out on a Nonius KappaCCD diffractometer with a rotating anode, using graphitemonochromated Mo K $\alpha$ radiation $(\lambda=0.71073 \AA)\left(\mathbf{D}, \mathbf{9 b} \cdot \mathrm{H}_{2} \mathrm{O}\right.$, and 13b) and an Enraf-Nonius CAD-4 diffractometer with graphite-monochromated Cu K $\alpha$ radiation $(\lambda=1.54180 \AA)$ (14c). The structures were solved by Patterson methods (DIRDIF-97,45 $\mathbf{9 b} \cdot \mathrm{H}_{2} \mathrm{O}$; DIRDIF $-99,{ }^{46} \mathbf{1 4 c}$ ) or by direct methods (SIR-9747 for D and SHELXS-9748 for $\mathbf{1 3 b}$ ). The structures of D, $\mathbf{9 b} \cdot \mathrm{H}_{2} \mathrm{O}$, and $\mathbf{1 3 b}$ were refined with SHELXL-9749 against $\mathrm{F}^{2}$ values of all reflections. Non-hydrogen atoms were refined with anisotropic displacement parameters, and hydrogen atoms were refined as rigid groups (D and $\mathbf{1 3 b}$ ). In the structure of $\mathbf{9 b} \cdot \mathrm{H}_{2} \mathrm{O}$ the hydrogens were refined freely with isotropic displacement parameters. Structure $\mathbf{1 3 b}$ contains large voids with a volume of $2117.3 \AA^{3} /$ unit cell. These voids are filled with disordered solvent molecules. Their contribution to the structure factors was secured by back-Fourier transformation using the SQUEEZE routine of the program PLATON, ${ }^{50}$ amounting to 620 electrons/unit cell. For $\mathbf{1 4 c}$ the

(45) Beurskens, P. T.; Admiraal, G.; Beurskens, G.; Bosman, W. P.; Garcia-Granda, S.; Gould, R. O.; Smits, J . M. M.; Smykalla, C. DIRDIF97; University of Nijmegen, Nijmegen, The Netherlands, 1997.

(46) Beurskens, P. T.; Beurskens, G.; de Gelder, R.; Garcia-Granda S.; Gould, R. O.; Israel, R.; Smits, J . M. M. DIRDIF-99; University of Nijmegen, Nijmegen, The Netherlands, 1999.

(47) Altomare, A.; Burla, M. C.; Camalli, M.; Cascarano, G. L.; Giacovazzo, C.; Guargliardi, A.; Moliterni, A. G. G.; Polidori, G.; Spagna, R. J. Appl. Crystallogr. 1999, 32, 115.

(48) Sheldrick, G. M. SHELXS-97; University of Göttingen, Göttingen, Germany, 1997.

(49) Sheldrick, G. M. SHELXL-97; University of Göttingen, Göttingen, Germany, 1997.

(50) Spek, A. L. PLATON; Utrecht University, Utrecht, The Netherlands, 2003. 
calculations were performed with $\mathrm{XTAL},{ }^{51}$ and hydrogen atoms were calculated and kept fixed with $U=0.10 \AA^{2}$. Full-matrix least-squares refinement on $F$, anisotropic for the nonhydrogen atoms except for the methyl groups of the tert-butyls, converged to $\mathrm{R}=0.053, \mathrm{R}_{\mathrm{w}}=0.063,(\Delta / \sigma)_{\max }=0.03, \mathrm{~S}=1.09$. Refining the inverted structure converged to $R=0.066$, thus confirming the absolute structure. The structure contains two independent identical molecules in the asymmetric unit. Matching molecule A with the inverted molecule B led to a

(51) Hall, S. R.; du Boulay, D. J .; Olthof-Hazekamp, R. XTAL 3.7 System; University of Western Australia, Lamb, Perth, Australia, 2000.

(52) Blessing, R. H. J . Appl. Crystallogr. 1997, 30, 421-426.

(53) North, A. C. T.; Phillips, D. C.; Mathews, F. S. Acta Crystallogr. 1968, A26, 351-359. rms value of $0.12 \AA$. Other details of the structure determinations are given in Table 7.

Acknowledgment. This work was supported in part (W.J .H., A.L.S., M.L.) by The Netherlands F oundation for Chemical Sciences (CW) with financial aid from The Netherlands Organization for Scientific Research (NWO). We wish to thank Han Peeters for performing the mass spectrometric measurements.

Supporting Information Available: X-ray CIF files for compounds $\mathbf{D}, \mathbf{9} \mathbf{b} \cdot \mathrm{H}_{2} \mathrm{O}, \mathbf{1 3} \mathbf{b}$, and $\mathbf{1 4}$. This material is available free of charge via the Internet at http://pubs.acs.org.

OM049619Q 